\title{
Ambient ozone pollution at a coal chemical industry city in the border of Loess Plateau and Mu Us Desert: Characteristics, sensitivity analysis and control strategies
}

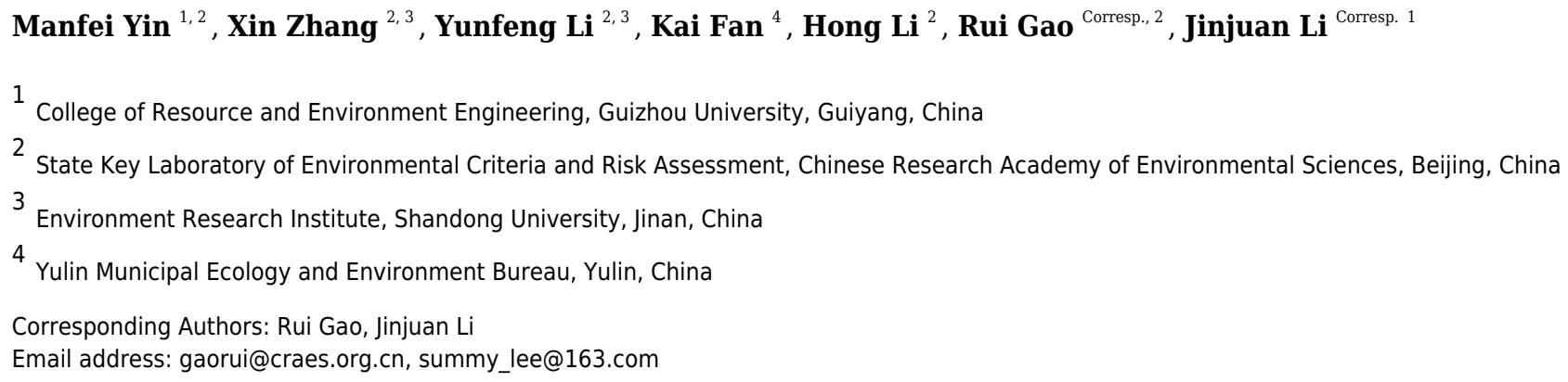

In this study, ambient ozone $\left(\mathrm{O}_{3}\right)$ pollution characteristics and sensitivity analysis were carried out in Yulin, a city in the central area of the Loess Plateau during 2017 to 2019 summer. $\mathrm{O}_{3}$ concentrations increased for 2017 to 2019. Correlation and statistics analysis indicated high temperature $\left(\mathrm{T}>25^{\circ} \mathrm{C}\right)$, low relative humidity $(\mathrm{RH}<60 \%)$, and low wind speed (WS $<3 \mathrm{~m} / \mathrm{s}$ ) were favorable for $\mathrm{O}_{3}$ formation and accumulation, and the $\mathrm{O}_{3}$ pollution days (MDA8 $\mathrm{O}_{3}>160 \mu \mathrm{g} / \mathrm{m}^{3}$ ) were predominantly observed when the wind was traveling from the easterly and southerly. $\mathrm{O}_{3}$ concentration in urban area of Yulin was higher than that in background. The pollution air masses from Fenwei Plain increase the level and duration of $\mathrm{O}_{3}$ pollution. In order to clarify the formation mechanism and source of $\mathrm{O}_{3}$, online measurements of volatile organic compounds (VOCs) were conducted from 7 July to 10 August in 2019. The average of VOCs concentration was $26 \pm 12$ ppbv, and large amounts of alkenes followed by aromatics, characteristic pollutants of the coal chemical industry, were detected in the ambient air. To further measure the sensitivity, the observation-based model (OBM) simulation was conducted. Empirical Kinetic Modeling Approach (EKMA) plot and relative incremental reactivity (RIR) value indicated Yulin located on VOCs-limited regime. That implied a slight decrease of $\mathrm{NO}_{x}$ may increase $\mathrm{O}_{3}$ concentration. When the emission reduction ratio of anthropogenic $\mathrm{VOCs} / \mathrm{NO}_{x}$ higher than $1: 1$, the $\mathrm{O}_{3}$ will decrease. $\mathrm{O}_{3}$ control strategies analysis shows that the $\mathrm{O}_{3}$ targets of $5 \%$ and $10 \% \mathrm{O}_{3}$ concentration reductions are achievable through precursor control, but more effort is needed to reach the $30 \%$ and $40 \%$ reduction control targets. 
1 Ambient ozone pollution in a coal chemical industry

2 city at the border of Loess Plateau and Mu Us Desert:

3 Characteristics, sensitivity analysis, and control

4 strategies

5 Manfei Yin ${ }^{1,2}$, Xin Zhang ${ }^{2,3}$, Yunfeng $\mathrm{Li}^{2,3}$, Kai Fan ${ }^{4}$, Hong Li², Rui Gao ${ }^{2^{*}}$, Jinjuan $\mathrm{Li}^{1^{*}}$

$6{ }^{1}$ College of Resource and Environment Engineering, Guizhou University, Guiyang, China

$7 \quad 2$ State Key Laboratory of Environmental Criteria and Risk Assessment, Chinese Research

8 Academy of Environmental Sciences, Beijing, China

$9{ }^{3}$ Environment Research Institute, Shandong University, Qingdao, China

$10{ }^{4}$ Yulin Municipal Ecology and Environment Bureau, Yulin, China

11

Corresponding Author:

13 Rui Gao ${ }^{2}$

14 Chaoyang District, Beijing, China

15 Email address: gaorui@craes.org.cn

17 Jinjuan $\mathrm{Li}^{1}$

18 Guiyang, China

19 Email address: summy_lee@163.com 


\section{Abstract}

22 In this study, we carried out ambient ozone $\left(\mathrm{O}_{3}\right)$ pollution characteristic and sensitivity analyses 23 in Yulin, a city in the central area of the Loess Plateau, during summers from 2017 to 2019. $\mathrm{O}_{3}$ 24 concentrations increased between 2017 and 2019. Correlation and statistics analyses indicated 25 that high temperatures $\left(\mathrm{T}>25^{\circ} \mathrm{C}\right)$, low relative humidity $(\mathrm{RH}<60 \%)$, and low wind speed $26(\mathrm{WS}<3 \mathrm{~m} / \mathrm{s})$ were favorable for $\mathrm{O}_{3}$ formation and accumulation, and that $\mathrm{O}_{3}$ pollution days $27 \quad\left(\mathrm{MDA} 8 \mathrm{O}_{3}>160 \mu \mathrm{g} / \mathrm{m}^{3}\right)$ were predominantly observed when the wind was traveling from the east 28 and south. $\mathrm{O}_{3}$ concentrations in Yulin's urban area were higher than that of the background. The 29 pollution air masses from the Fenwei Plain increased the $\mathrm{O}_{3}$ pollution levels and duration. In order to identify the $\mathrm{O}_{3}$ formation mechanism and source, we collected online measurements of volatile organic compounds (VOCs) between 7 July and 10 August 2019. The average VOC concentration was $26 \pm 12 \mathrm{ppbv}$, and we detected large amounts of alkenes, as well as aromatics (characteristic pollutants of the coal chemical industry), in the ambient air. The observationbased model (OBM) simulation was conducted to further measure sensitivity. The Empirical Kinetic Modeling Approach (EKMA) plot and relative incremental reactivity (RIR) values showed that Yulin was located in a VOC-limited regime, where a slight decrease in $\mathrm{NO}_{\mathrm{x}}$ may increase $\mathrm{O}_{3}$ concentration. When the anthropogenic $\mathrm{VOC} / \mathrm{NO}_{\mathrm{x}}$ emission reduction ratio is higher than $1: 1$, the $\mathrm{O}_{3}$ will decrease. $\mathrm{O}_{3}$ control strategy analysis shows that $5 \%$ and $10 \% \mathrm{O}_{3}$ concentration reduction targets are achievable through precursor control, but more effort is needed to reach the $30 \%$ and $40 \%$ reduction control targets.

\section{Introduction}

China's ozone $\left(\mathrm{O}_{3}\right)$ concentrations have shown a gradual upward trend over recent years. Studies on China's $\mathrm{O}_{3}$ pollution in China have focused on more developed regions, such as BeijingTianjin-Hebei (BTH) (Duan et al., 2008; Xu et al., 2011; Zhang et al., 2014b; Yan et al., 2016b), the Yangtze River Delta (YRD) (Wang et al., 2020b; Zhang et al., 2020b), the Pearl River Delta (PRD) (Chen et al., 2019; He et al., 2019), and the Guanzhong Plain (GZP) (Hui et al., 2021), which is close to the Loess Plateau. However, few studies have been conducted on the Loess Plateau itself (Li et al., 2020a; Li et al., 2020b; Wang et al., 2012). The Loess Plateau is to the north of central China, and is one of the country's four major plateaus. Since much of its arid surface is exposed, it becomes a source of suspended particulate matter (PM) that pollutes cities in north China during dry and windy weather (Cao et al., 2008a). China began carrying out vegetation rehabilitation programs in 1978 ( $\mathrm{Li}$ et al., 2017). With stricter air pollution control and the increase of comprehensive studies on PM between 2014 and 2017 (Cao et al., 2008a; Cao et al., 2008b; Liu et al., 2004; Wang et al., 2011; Zhang et al., 2014a; Xiaoye, 2002), the $\mathrm{PM}_{2.5}$ pollution problem plaguing Loess Plateau, and many other parts of China (Cao et al., 2012; Zhang et al., 2019), has been effectively alleviated, while $\mathrm{O}_{3}$ concentrations continue to rise. $\mathrm{O}_{3}$ has become the primary pollutant affecting Loess Plateau's ambient air quality in the summer. 
61

62

63

64

65

66

67

68

69

70

71

72

73

74

75

76

77

78

79

80

81

82

83

84

85

86

87

88

89

90

91

92

93

94

95

96

97

98

99

100

Yulin $(38.25 \mathrm{~N}, 109.73 \mathrm{E})$ is located in the central area of Loess Plateau, in the northernmost part of Shaanxi Province (Zhu et al., 2019). It is in the junction area of Jin-Shan-Meng-Ning (Shanxi, Shaanxi, Inner Mongolian, and Ningxia provinces), which is one of China's five main coal production areas and one of the main battlefields for coal exploitation in China (Hao et al., 2019). Yulin is a typical energy resource city, with proven coal reserves of $2.7 \times 10^{3}$ billion tons. In 2019 , the output of raw coal alone was $4.6 \times 10^{5}$ kilo-tons. The area's rapid development and energy advantages (Zhai et al., 2020) have caused many environmental problems. Previous research on this area mainly focused on PM. Lei et al. (2018) found that Yulin's high $\mathrm{Ca}^{2+}$ levels during winter and autumn are attributed to fugitive dust, while high spring and summer sulfate levels are caused by different sources. Ion balance studies illustrated that $\mathrm{PM}_{10}$ samples were more alkaline than $\mathrm{PM}_{2.5}$ samples. Wang et al. (2011) found that dust aerosol invading Yulin could be from the northwestern desert in China and the Gobi Desert in Mongolia. CO and PM 10 levels decreased while $\mathrm{PM}_{2.5}, \mathrm{O}_{3}$, and $\mathrm{NO}_{2}$ levels increased (Fig. S1). $\mathrm{PM}_{2.5}$ and $\mathrm{O}_{3}$ were the primary pollutants in winter and summer, respectively. Very few studies have reported on this rise of $\mathrm{O}_{3}$ concentrations ( $\mathrm{Li}$ et al., 2020a; Hou et al., 2006). It is critical to explore the effect of local generation and transport on Yulin's $\mathrm{O}_{3}$ levels.

In this paper, we analyzed the temporal and spatial characteristics of $\mathrm{O}_{3}$ and the influence of meteorological factors from 2017-2019. We used the observation-based (OBM) model to study the sensitivity of $\mathrm{O}_{3}$ formation to VOCs and $\mathrm{NO}_{x}$ between July and August 2019. Additionally, we set several targets in our discussion of $\mathrm{O}_{3}$ control strategies.

\section{Materials \& Methods}

Measurement data

To evaluate Yulin's $\mathrm{O}_{3}$ characteristics between 2017 and 2019, we obtained observational hourly concentrations of air pollutants including $\mathrm{O}_{3}, \mathrm{CO}, \mathrm{NO}_{2}, \mathrm{PM}_{10}, \mathrm{PM}_{2.5}$, and $\mathrm{NO}$, as well as meteorological parameters including temperature $(\mathrm{T})$, relative humidity $(\mathrm{RH})$, wind speed (WS), and wind direction (WD) from National Environmental Monitoring Stations and the Yulin Ecology and Environment Bureau. In Yulin, we chose four stations for study: the Environmental Monitoring Building (EMB, 38.25 $\left.\mathrm{N}, 109.73^{\circ} \mathrm{E}\right)$, Experimental Middle School (EMS, $38.28^{\circ}$ $\left.\mathrm{N}, 109.73^{\circ} \mathrm{E}\right)$, Century Square $\left(\mathrm{CS}, 38.29^{\circ} \mathrm{N}, 109.48^{\circ} \mathrm{E}\right)$, and Hongshixia Gorge Eco-Park $\left(\right.$ HGEP, $\left.38.33^{\circ} \mathrm{N}, 109.74^{\circ} \mathrm{E}\right)$. The locations of the four stations are presented in Fig. 1. There are no significant local sources close to these four sites. Ambient Air Quality Monitoring Specification (on trial) (Chinese HJ 664-2013) classified the EMB site, EMS site, and CS site as urban assessing stations and the HGEP site as an urban background station. Urban assessing stations are set up to monitor ambient air quality and changing trends in urban built-up, and participate in the assessment of urban ambient air quality. Urban background stations monitor the ambient air quality in urban areas that are not affected by local urban pollution and do not participate in the assessment of urban ambient air quality. The EMB site is surrounded by a residential area and processing, manufacturing, and coal chemical industries are located about 5 
$101 \mathrm{~km}$ south. The EMS site and CS site are in mixed functional areas of commerce, transportation,

102

103

104

105

106

107

108

109

110

111

112

113

114

115

116

117

118

119

120

121

122

123

124

125

126

127

128

129

130

131

132

133

134

135

136

137

138

139

140 and residences. Although the HGEP site is regulated as an urban background station, it was surrounded by a highway during our field survey and many trucks passed through it.

To investigate the characteristics of VOCs and their contribution to $\mathrm{O}_{3}$ formation in Yulin, we coupled online gas chromatography with a mass spectrometer and a flame ionization detector (GC-MS/FID, AC-GCMS 1000) developed by Guangzhou Hexin Instrument Co., Ltd. This was used to measure VOC levels at the EMB site from 7 July to 10 August 2019. A total of 70 VOCs (18 alkanes, 11 alkenes, one ethyne, 16 halocarbons, 14 aromatics, and 10 oxygenated VOCs (OVOCs)) were measured concurrently with $1 \mathrm{~h}$ resolution. The air passed over two cold traps in the separate FID and MS routes, and samples were rapidly heated and vaporized at a rate of up to $50^{\circ} \mathrm{C} / \mathrm{s}$. The VOCs were brought into the FID and MS for online qualitative and quantitative analysis, respectively. The $\mathrm{C}_{2}-\mathrm{C}_{4}$ hydrocarbons were analyzed by the FID and the high carbon components were analyzed by the MS. To check the stability of the monitoring system, we injected the mixed standard gas (Photochemical Assessment Monitoring Stations (PAMS)) and the US Environmental Protection Agency toxic organics (TO-15)) with a concentration of 1ppb into the system seven times, and calculated the relative standard deviation (RSD) of the concentration for each component. The results showed that the RSD of all VOCs was lower than $10 \%$ (Table S1). A seven-point calibration curve was made using the standard gas external standards with the linearity $\left(\mathrm{R}^{2}\right)$ of each VOC species exceeding 0.99 . Another standard gas was injected daily into the instrument to test the system performance at 23:00. Therefore the data from 23:00 local time (LT) were excluded in this study.

\section{Backward trajectory analysis}

The $48 \mathrm{~h}$ backward trajectories from May to August 2017 to 2019 were computed using the Hybrid Single-Particle Lagrangian Integrated Trajectory (HYSPLIT) model (Cohen et al., 2015; Draxler and Hess, 1998) with 6-h intervals and a start time of 00:00 LT to identify the origins of air masses $1,000 \mathrm{~m}$ above sea level. The meteorological data were provided by the Global Data Assimilation System of the United States National Centers for Environmental Prediction (ftp://arlftp.arlhq.noaa.gov/pub/archives/gdas1). These backward trajectories from 2017, 2018, and 2019 were analyzed using HYSPLIT, and then were categorized into a few clusters for analysis of the influence of $\mathrm{O}_{3}$ regional transported sources.

\section{Observational-based model}

The OBM was developed by Cardelino \& Chameides (1995) and was built on the newest version of the Master Chemical Mechanism (MCM v3.3.1; http://mcm.leeds.ac.uk/MCM/), a nearexplicit mechanism describing the oxidation reactions of 146 primary VOCs together with the latest inorganic chemistry from the International Union of Pure and Applied Chemistry evaluation (He et al., 2020). Hourly concentrations of VOCs and four trace gases $\left(\mathrm{SO}_{2}, \mathrm{CO}, \mathrm{NO}\right.$, and $\mathrm{NO}_{2}$ ), as well as hourly meteorological parameters (temperature and relative humidity), were

Peer] reviewing PDF | (2021:01:57042:1:1:NEW 24 Mar 2021) 
141 used as inputs to constrain the model (Lyu et al., 2019). Moreover, this model can be employed

142 to assess the sensitivity of $\mathrm{O}_{3}$ photochemical production by calculating the relative incremental

143 reactivity (RIR) and changing the concentrations of its precursors without detailed or accurate

144 knowledge of these emissions (He et al., 2019):

$$
R I R(X)=\frac{\left[P_{O_{3}}(X)-P_{O_{3}}(X-\Delta X)\right] / P_{O_{3}}(X)}{\Delta S(X) / S(X)}
$$

146

147

148

149

150

151

152

153

154

155

156

157

158

159

160

161

162

163

164

165

166

167

168

169

170

In the PMF model, Q was the sum of the squared residual weighted by the inverse of their respective measurement uncertainty and in order to minimize the value. Q can be described as:

$$
Q=\sum_{i=1}^{n} \sum_{j=1}^{m}\left(\frac{X_{i j}-\sum_{k=1}^{p} g_{i k} e_{k j}}{S_{i j}}\right)
$$

where $\mathrm{X}$ is a precursor of $\mathrm{O}_{3}$ and $\triangle \mathrm{X}$ represents the change in $\mathrm{X}$ concentrations; $\mathrm{P}\left(\mathrm{O}_{3}\right)$ is the $\mathrm{O}_{3}$ net production rate, which is calculated by the OBM; $\mathrm{S}(\mathrm{X})$ is the measured concentration of precursor $X$, and $\triangle S(X) / S(X)$ represents the relative change of $S(X)(20 \% S(X)$ in this study).

\section{Positive matrix factorization model}

The positive matrix factorization (PMF) model is used to interpret source types and contributions based on VOC concentrations obtained from receptor point measurements (Paatero \& Tapper, 1994). It has been used for the source apportionment of VOCs (Sun et al., 2020). In this study, we used PMF 5.0 to identify and quantify the main VOC sources in Yulin. A detailed description of the PMF model can be found in the EPA PMF 5.0 User Guide. Briefly, the ambient VOC observations matrix (x) was decomposed into two matrices: source profile (f) and source contribution $(\mathrm{g})$ :

$$
x_{i j}=\sum_{k=1}^{p} g_{i k} f_{k j}+e_{i j}
$$

where, $x_{i j}$ is the concentration of species $j$ measured in sample $i$; $g_{i k}$ is the contribution of the source $k$ to the sample $i ; f_{k j}$ is the profile of the species $i$ in the source $k$; $e_{i j}$ is the residual of species $\mathrm{j}$ in sample $\mathrm{i}$; and $\mathrm{p}$ represents the total number of sources (Fan et al., 2020). In this study, we measured 70 VOC species and divided these species into three categories according to their signal-to-noise ratio $(\mathrm{S} / \mathrm{N})$ and detection limit (BDL). In general, species were classified as strong if the $\mathrm{S} / \mathrm{N}$ was $>2$, weak if the $\mathrm{S} / \mathrm{N}$ was between 0.2 and 2 or if the BDL percentage was $>$ $50 \%$, and bad if the $\mathrm{S} / \mathrm{N}$ was $<0.2$ or if the BDL percentage was $>60 \%$ (Hui et al., 2020). Ultimately, 46 VOC species were selected and served as inputs of the PMF model.
171

172

173

Ideally, the modeled $Q$ value should eventually approach the expected $Q$ values $\left(Q_{\exp }\right)$, which are equal to the degree of freedom of the model solution $(n \times m-p(n+m)$ (Yan et al., 2016a).

\section{Results}




\section{Temporal $\mathbf{O}_{3}$ distribution characteristics}

175 According to the Chinese Technical regulation for ambient air quality assessment (on trial) 176 (Chinese $\mathrm{HJ}$ 663-2013), 1-hour average $\mathrm{O}_{3}$ concentrations and daily maximum 8-hour average $177 \mathrm{O}_{3}$ concentrations (MDA8) are employed to describe hourly and daily $\mathrm{O}_{3}$ variations, respectively. 178 The $90^{\text {th }}$ percentile of daily maximum 8-h average of $\mathrm{O}_{3}$ concentrations (MDA8-90) is employed 179 to evaluate monthly and annual $\mathrm{O}_{3}$ concentration levels. In this study, we used both MDA8 and 180 maximum daily 1-hour average $\mathrm{O}_{3}$ concentrations (MDA1) to present daily mean and extreme $181 \mathrm{O}_{3}$ concentrations. The Ambient Air Quality Standard (Chinese GB3095-2012) regulates the 182 Grade II Standard of MDA8 and MDA1 $\mathrm{O}_{3}$, and are $160 \mu \mathrm{g} / \mathrm{m}^{3}$ (about $75 \mathrm{ppbv}$ ) and $200 \mu \mathrm{g} / \mathrm{m}^{3}$ 183 (about $93 \mathrm{ppbv}$ ), respectively. We defined the day when MDA8 or MDA1 $\mathrm{O}_{3}$ levels exceeded 184 the Grade II Standard as $\mathrm{O}_{3}$ pollution day. Moreover, we also evaluated the diurnal, monthly, and annual variations observed in Yulin. The HGEP site was an urban background station which, according to technical regulation for the selection of ambient air quality monitoring stations (on trial) in China, are not included in the evaluation of a city's air quality. Therefore, the HGEP site data were not included in the description of ambient $\mathrm{O}_{3}$ changes in Yulin.

189

As shown in Table 1 , the mean MDA8 $\mathrm{O}_{3}$ concentration, MDA8-90 $\mathrm{O}_{3}$ concentration, and 191 pollution days all showed a rising trend from 2017 to 2019. Previous studies found that the average MDA8 $\mathrm{O}_{3}$ concentration for China's 31 capital cities in 2013 and 2017 was 61 and 76 ppbv, respectively (Zeng et al., 2019). In the YRD, the average MDA8 $\mathrm{O}_{3}$ concentration was 78 ppbv in 2018 ( $\mathrm{Li}$ et al., 2019). In Lanzhou, China, the average MDA8 $\mathrm{O}_{3}$ concentration from 2013 to 2015 was $68.26 \mu \mathrm{g} / \mathrm{m}^{3}$ (about $32 \mathrm{ppbv}$ ) (Wang et al., 2017b). The average MDA8 $\mathrm{O}_{3}$ concentration in the GZP was $96 \mu \mathrm{g} / \mathrm{m}^{3}$ (about $45 \mathrm{ppbv}$ ) in 2019 (http://sthjt.shaanxi.gov.cn/zfxxgk/hjzl/hjzkgb/20201130/64307.html). Generally, $\mathrm{O}_{3}$ concentrations in Yulin were lower than developed areas such as cities in the YRD, comparable to the national average level and the GZP, and higher than Lanzhou.

200

201

The $\mathrm{O}_{3}$ pollution days all occurred between May and August in 2017 and 2018. One 202 unanticipated finding was that $\mathrm{O}_{3}$ pollution days also appeared in April and September in 2019.

203

204

205

206

207

208

209

210

211

212

213
The T, RH, and WS averages in April and September 2019 were $15^{\circ} \mathrm{C}$ and $19^{\circ} \mathrm{C}, 43 \%$ and $65 \%$, and $1.7 \mathrm{~m} / \mathrm{s}$ and $1.3 \mathrm{~m} / \mathrm{s}$, respectively. The T, RH, and WS averages in April and September 2017 to 2019 were $14^{\circ} \mathrm{C}$ and $18^{\circ} \mathrm{C}, 41 \%$ and $61 \%$, and $1.8 \mathrm{~m} / \mathrm{s}$ and $1.5 \mathrm{~m} / \mathrm{s}$, respectively (Table S2). The meteorological conditions in April and September 2019 were not significantly different from those in 2017 and 2018. Two $\mathrm{O}_{3}$ pollution days occurred consecutively from 18 to 19 April 2019. On 18 April, the $\mathrm{O}_{3}$ concentration peaked at 19:00 LT, decreased to $51.3 \mathrm{ppbv}$ the next day at 5:00, and then started to increase again. Relatively high $\mathrm{O}_{3}$ concentration at night could be explained by regional transportation. Six consecutive $\mathrm{O}_{3}$ pollution days occurred from 3 to 8 September 2019. Unlike the $\mathrm{O}_{3}$ pollution days in April, regional transportation was not the primary reason for this $\mathrm{O}_{3}$ pollution episode. The average $\mathrm{NO}_{2}$ concentrations from 3 to 8 September were $20,22,27,28,22$, and $21 \mathrm{ppbv}$, respectively, which were higher than the 
214 average concentrations on adjacent days, such as 2 September (16.6 ppbv) and 9 September 215 (12.8 ppbv). This suggests that the continued increase in $\mathrm{O}_{3}$ concentration may have been closely 216 related to the increase in nitrogen dioxide concentration.

217

218

219

220

221

222

223

224

225

226

227

228

229

230

231

232

233

234

235

236

237

238

239

240

241

242

243

244

245

246

247

248

249

250

251

252

253

Fig. 2a displays the monthly $\mathrm{O}_{3}$ variations. The highest MDA8-90 $\mathrm{O}_{3}$ concentrations in 2017, 2018, and 2019 were 40, 39, and 39 ppbv, respectively. The highest MDA8-90 $\mathrm{O}_{3}$ concentration appeared in May 2017 and June 2019. MDA8-90 O 3 concentrations in May to July 2017-2019 exceeded the Grade II Standard. Additionally, the MDA8-90 $\mathrm{O}_{3}$ concentration in April and September 2019 also exceeded the standard. Monthly $\mathrm{O}_{3}$ variations reflected an obvious seasonal cycle, as $\mathrm{O}_{3}$ concentrations were high in summer and spring and low in winter and autumn. Some areas in north China also show this kind of seasonal cycle (Fang et al., 2020; Yan et al., 2016b; Wang et al., 2012; Li et al., 2020a). This seasonal $\mathrm{O}_{3}$ variation was largely influenced by meteorological conditions (Wang et al., 2020b; Zheng et al., 2019).

The diurnal variation of $\mathrm{O}_{3}$ concentrations is driven by photochemical reactions, meteorological conditions, the transport of $\mathrm{O}_{3}$ and its precursors, and surface deposition (Crutzen, 2016; David \& Nair, 2011). The diurnal variation in Yulin from 2017-2019, similar to many cities in northern China, shows a typical single peak curve: a valley in early morning and a peak in afternoon (Fig. 2b; Wang et al., 2012; Yu et al., 2020b; Li et al., 2020a). It was apparent that the $\mathrm{O}_{3}$ concentrations were highest in summer, then spring, autumn, and winter. The $\mathrm{O}_{3}$ concentration peaks were 60, 67, 43, and $34 \mathrm{ppbv}$ in spring, summer, autumn, and winter, respectively. The peaks occurred at 16:00 LT in spring, autumn, and winter, but at 15:00 LT in summer. The solar radiation on Loess Plateau is intense, especially in summer, which can lead to more efficient $\mathrm{O}_{3}$ production (Hu et al., 2014).

\section{Spatial $\mathrm{O}_{3}$ distribution characteristics}

The four Yulin sites from most south to most north are the EMB, EMS, CS, and HGEP. Fig. 3 shows that $\mathrm{O}_{3}$ concentrations decreased spatially from south to north between 2017 and 2018. In 2017, the EMB site had the highest $\mathrm{O}_{3}$ concentration, followed by the CS site, then the EMS site, and the HGEP site. In 2018, the $\mathrm{O}_{3}$ concentrations decreased from south to north. In 2019, the EMB site had the highest $\mathrm{O}_{3}$ concentration, followed by the HGEP site, then the EMS site, and the CS site, implying that the central region had lower $\mathrm{O}_{3}$ concentrations than the northern and southern regions. The EMB site had the highest concentrations between 2017 and 2019. This suggested that Yulin's $\mathrm{O}_{3}$ concentration was greatly affected by industry. Diurnal and monthly variations at the four sites showed the same trend (Fig. S2). The diurnal variation curve showed that the lowest concentrations appeared at 7:00 LT in the morning and the highest concentrations appeared at 16:00 LT in the afternoon. The distance between these sites is less than $5 \mathrm{~km}$. Therefore, different pollution sources can explain the differences in $\mathrm{O}_{3}$ concentrations at the four sites. 
254 The HGEP site's $\mathrm{O}_{3}$ concentration increased from 2017 to 2019 but was lower than that of

255 Yulin's urban area. The monthly and daily changes were consistent with those of the urban area. 256 However, the $\mathrm{O}_{3}$ concentrations were lower at night at the HGEP site than at the other sites (Fig. 257 S2a). As mentioned above, the HGEP site is a traffic-intensive area, and vehicles emit NO that 258 can titrate and lower $\mathrm{O}_{3}$ levels.

\section{Overview of $\mathrm{O}_{3}$ pollution during the VOC sampling period}

260 To further reveal the impact of $\mathrm{O}_{3}$ local formation, we collected VOC samples at the EMB site

261

262

263

264

265

266

267

268

269

270

271

272

273

274

275

276

277

278

279

280

281

282

283

284

285

286

287

288

289

290

291

292

293

from 7 July to 10 August 2019. Fig. 4 shows the time series of the meteorological factors and $\mathrm{NO}_{2}, \mathrm{CO}, \mathrm{PM}_{2.5}, \mathrm{PM}_{10}$, VOC, and $\mathrm{O}_{3}$ concentrations in Yulin during the VOC sampling period. The average values are listed in Table $\mathrm{S} 3$. We regarded consecutive MDA8 $\mathrm{O}_{3}$ pollution days as one $\mathrm{O}_{3}$ episode period (EP). There were a total of six $\mathrm{O}_{3}$ episode periods (EP1: 11-14 July, EP2: 20 July, EP3: 25-26 July, EP4: 28 July, EP5: 30 July-2 August, and EP6: 10 August) observed during the sampling period. During the sampling period, the average MDA8 $\mathrm{O}_{3}$ concentration was $72 \pm 9 \mathrm{ppbv}$ with a range from $50 \mathrm{ppbv}$ to $85 \mathrm{ppbv}$, and $83 \pm 2,75,82 \pm 3,77,79 \pm 3$ and 84 ppbv, respectively, from EP1 to EP6. The average concentration of total VOCs was $26 \pm 12$ ppbv with a wide range from 6 to $90 \mathrm{ppbv}$, and 30,41,28, 27, 31, and 13 ppbv, respectively, in the EPs. The meteorological factors of these six EPs (Table S3) were beneficial to in situ photochemical processes. $\mathrm{NO}_{2}$ and total volatile organic compound (TVOC) concentrations were higher than in the non-pollution period. This indicated an increase in local precursor emissions. The valley values on 26 July (EP3), 28 July (EP4), 2 August (EP5), and 10 August (EP6) were 31, 22 50, and $33 \mathrm{ppbv}$, respectively. Compared to the average valley value during the VOC sampling period (19 ppbv) and the median value (16 ppbv), these valley values were relatively high. This result implied that EP3, EP4, EP5, and EP6 were also affected by regional transportation. The $48 \mathrm{~h}$ backward trajectories when hourly $\mathrm{O}_{3}$ concentrations were over $75 \mathrm{ppbv}$ are shown in Fig S3. Most of the backward trajectories of EP1 and EP2 came from local and southwest areas, respectively, and there were no $\mathrm{O}_{3}$ pollution areas along the trajectories. Most of the backward trajectories of EP3, EP4, and EP5 came from the Fenwei Plain, and $\mathrm{O}_{3}$ pollution also occurred in the cities along the trajectories (Table S4). However, during EP6, no pollution was found along the trajectories. This $\mathrm{O}_{3}$ EP was complex and the data cannot be explained. Determining whether the changes in $\mathrm{O}_{3}$ concentration were caused by transportation, meteorological conditions, or anthropogenic sources will be our focus in future studies.

Different VOC species are capable of influencing $\mathrm{O}_{3}$ formation potential (OFP), which can be estimated using Maximum Incremental Reactivity (MIR) (Carter, 2009). The $\mathrm{OH}$ reactivity concept is useful when estimating $\mathrm{VOC} \mathrm{O}_{3}$ production because VOC degradation caused by $\mathrm{OH}$ oxidation eventually leads to net $\mathrm{O}_{3}$ production (Tan et al., 2018). $\mathrm{OH}$ reactivity is the sum of the products of precursor $\mathrm{O}_{3}$ concentrations and the reaction rate constants between $\mathrm{O}_{3}$ precursors and $\mathrm{OH}$ (Atkinson \& Arey, 2004). The percentage contributions of alkanes, alkenes, ethyne, halocarbons, aromatics, oxygenated VOCs, and isoprene to the mixing ratio, $\mathrm{L}_{\mathrm{OH}}$, and OFP of total VOCs are shown in Fig. 5. Among these, alkanes were the most abundant VOC species,

Peer) reviewing PDF | (2021:01:57042:1:1:NEW 24 Mar 2021) 
294

295

296

297

298

299

300

301

302

303

304

305

306

307

308

309

310

311

312

313

314

315

316

317

318

319

320

321

322

323

324

325

326

327

328

329

330

331

332

333

accounting for $46.2 \%$, followed by OVOCs $(26.9 \%)$, alkenes $(10.1 \%)$, aromatics $(7.8 \%)$, ethyne $(4.3 \%)$, halocarbons $(4.3 \%)$, and isoprene $(0.4 \%)$. Although alkanes were the most abundant VOC species in Yulin, the proportions of $\mathrm{L}_{\mathrm{OH}}(12.7 \%)$ and OFP (14.0\%) were relatively small. Alkenes (31.8\%), OVOCs (31.7\%), and aromatics (21.3\%) were the top three VOC species in terms of OFP proportion. $\mathrm{L}_{\mathrm{OH}}$ and OFP showed good consistency, and alkenes (44\%), OVOCs (23.5\%), and aromatics (12.8\%) had the top three proportions of $\mathrm{L}_{\mathrm{OH}}$. In previous studies, aromatics accounted for the highest $\mathrm{OFP}$ and $\mathrm{L}_{\mathrm{OH}}$ proportions in the PRD (Yu et al., 2020a; Tan et al., 2019). In Xi'an, the capital of Shaanxi Province, alkenes have been shown to have the highest proportion of $\mathrm{L}_{\mathrm{OH}}$ and OFP (Song et al., 2020). The OFP of sampling sites around Lanzhou were mainly from aromatics, which accounted for $46.3 \%$ (Wu et al., 2019), due to the petrochemical industry there. Due to its abundant coal resources, Yulin has many coking plants. The exhaust gas from coking plants contains a lot of alkenes, the key species in $\mathrm{O}_{3}$ formation, and aromatics (Zhang et al., 2020c).

\section{Discussion}

\section{The impact of meteorological parameters on $\mathrm{O}_{3}$ concentration}

Liu \& Wang (2020) used the Community Multiscale Air Quality (CMAQ) modeling system and found that the impact of meteorological factors on $\mathrm{O}_{3}$ trends varied by region and by year. Between 2013 and 2017, $\mathrm{O}_{3}$ concentrations in China were affected by meteorological factors, which showed comparable or even greater effects than anthropogenic emissions. Meteorological conditions such as $\mathrm{T}, \mathrm{RH}, \mathrm{WS}$, and WR directly affect surface $\mathrm{O}_{3}$ concentrations via changes in chemical reaction rates, dilution, wet and dry removal, and transport flux, or indirectly via changes in natural emissions (Lu et al., 2019b; Li et al., 2020c). We focused on the relationship between meteorological parameters ( $\mathrm{T}, \mathrm{RH}, \mathrm{WS}$, and WR) and $\mathrm{O}_{3}$ concentrations between May to August from 2017 to 2019 because $\mathrm{O}_{3}$ pollution days mainly occurred during this period. The correlational analysis results are shown in Table 2. Table S5 shows the total number of days, number of MDA8 and MDA1 $\mathrm{O}_{3}$ pollution days, and MDA8 and MDA1 $\mathrm{O}_{3}$ exceedance probabilities in different ranges of $\mathrm{T}, \mathrm{RH}, \mathrm{WS}$, and WR. The $\mathrm{O}_{3}$ exceedance probability was calculated using the percentage of the number of $\mathrm{O}_{3}$ pollution days across the total number of days. The influence of wind speed on ground $\mathrm{O}_{3}$ concentrations was insignificant $(-0.088)$. This result matches those in earlier studies (Chen et al., 2020; Fan et al., 2020).

$\mathrm{T}$ directly impacts chemical kinetic rates and the mechanistic pathway for $\mathrm{O}_{3}$ formation (Atkinson, 1990). High RH days were always associated with more cloud cover, which can reduce photochemistry (Kavassalis \& Murphy, 2017). The correlation coefficients between $\mathrm{T}$ and MDA8 $\mathrm{O}_{3}$ and MDA1 $\mathrm{O}_{3}$ were 0.547 and 0.519 , respectively. Between $\mathrm{RH}$ and MDA8 $\mathrm{O}_{3}$ and MDA $1 \mathrm{O}_{3}$, the correlation coefficients were -0.286 and -0.250 , respectively (Table 2). $\mathrm{O}_{3}$ was positively correlated with $\mathrm{T}$ and negatively correlated with RH. Further statistical test results are shown in Table S5. The MDA8 (MDA1) $\mathrm{O}_{3}$ exceedance probability of $\mathrm{T}$ in the ranges of 10$20^{\circ} \mathrm{C}, 20-30^{\circ} \mathrm{C}$, and over $30^{\circ} \mathrm{C}$ were $0.8 \%(0 \%), 27.7 \%(6.6 \%)$, and $81.82 \%(9.1 \%)$, respectively, 
334 and that of RH in the ranges of $20-40 \%, 40-60 \%, 60-80 \%$, and $80-100 \%$ were $22.6 \%(6.1 \%)$, $33531.3 \%(9.0 \%), 19.3 \%(2.3 \%)$, and $1.04 \%(0.0 \%)$, respectively. These results confirm that there is 336 a correlation between $\mathrm{O}_{3}$ and $\mathrm{T}$ and $\mathrm{RH}$. When $\mathrm{T}$ was higher than $30^{\circ} \mathrm{C}$ and $\mathrm{RH}$ was in the range 337 of $40-60 \%$, the probability of $\mathrm{O}_{3}$ pollution events was higher.

338 The correlation coefficients between WS and MDA8 $\mathrm{O}_{3}$ and MDA1 $\mathrm{O}_{3}$ were -0.088 and-0.164,

339

340

341

342

343

344

345

346

347

348

349

350

351

352

353

354

355

356

357

358

359

360

361

362

363

364

365

366

367

368

369

370

371

372

373 respectively, which indicated that the influence of WS on ground $\mathrm{O}_{3}$ concentrations was insignificant. Table $\mathrm{S} 5$ shows that the MDA8 (MDA1) $\mathrm{O}_{3}$ exceedance probability of WS in the range of $0-1.5 \mathrm{~m} / \mathrm{s}, 1.5-3 \mathrm{~m} / \mathrm{s}, 3-4.5 \mathrm{~m} / \mathrm{s}$, and greater than $4.5 \%$ were $22.5 \%(5.8 \%), 20.36 \%$ $(3.3 \%), 9.26 \%(1.85 \%)$, and $0 \%(0 \%)$, respectively. As WS increased, the exceedance probability showed a downward trend. Generally, the increase in WS caused $\mathrm{O}_{3}$ concentrations to decrease due to enhanced dry deposition, mixing, and dilution (Dawson et al., 2007). Additionally, WS and WR affected $\mathrm{O}_{3}$ concentrations by transporting $\mathrm{O}_{3}$ and its precursors. The MDA8 (MDA1) $\mathrm{O}_{3}$ exceedance probability of northerly, easterly, southerly, and westerly winds were $11.2 \%(5.1 \%), 28.0 \%(3.7 \%), 26.4 \%(5.7 \%)$, and $17.2 \%(5.7 \%)$, respectively. The effects of $\mathrm{T}, \mathrm{RH}$, and WS on MDA8 $\mathrm{O}_{3}$ and MDA1 $\mathrm{O}_{3}$ were similar. In contrast, the easterly winds showed the largest $\mathrm{O}_{3}$ exceedance probability of MDA8 $\mathrm{O}_{3}$ and the southerly and westerly winds showed the greatest MDA1 $\mathrm{O}_{3}$ exceedance probability. The results implied that $\mathrm{T}$ and $\mathrm{RH}$ can directly affect $\mathrm{O}_{3}$ formation and loss. However, the influence of wind on $\mathrm{O}_{3}$ concentrations was complex. In general, high $\mathrm{T}$, low $\mathrm{RH}$, and low WS were shown to cause $\mathrm{O}_{3}$ pollution, especially when the T exceeded $25^{\circ} \mathrm{C}$, the RH was less than $60 \%$, and the wind speed was less than $3 \mathrm{~m} / \mathrm{s}$. $\mathrm{O}_{3}$ pollution days were predominantly observed when the wind was traveling from the east and south.

\section{Regional transportation}

Besides local formation, long-distance regional transportation also plays an important role in increasing $\mathrm{O}_{3}$ concentration (Hui et al., 2018). Fig. 6a-c show the clustering analysis for May to August 2017 to 2019. In this study, when $\mathrm{O}_{3}$ concentrations were greater than 75 ppbv, we identified this backward trajectory as a polluted trajectory. In 2017, a total of 487 backward trajectories were categorized into five clusters. Cluster a1 to a5 accounted for $49 \%, 21 \%, 3 \%$, $13 \%$. and $10 \%$ of the total trajectories, respectively. There was a total of 44 polluted trajectories in 2017. Cluster a1 to a5 contained 27, five, two, one, and eight polluted trajectories, respectively. Cluster a1's air masses from Weinan in Shaanxi Province that crossed Yan'an to Yulin had the greatest impact on $\mathrm{O}_{3}$ concentrations in Yulin in 2017. In 2018, there was a total of 492 backward trajectories across five clusters. Cluster b1 to b5 accounted for 13\%,23\%, 27\%, $31 \%$, and $5 \%$ of the total trajectories, respectively. There was a total of 40 pollution trajectories in 2018. One, 10,13,12, and four pollution trajectories were grouped into clusters b1 to b5, respectively. Therefore, when the results of the cluster and the distribution of pollution trajectories were combined, the air masses of clusters b2, b3, and b4 had the greatest impact on the $\mathrm{O}_{3}$ in Yulin in 2018. Cluster b2 was from Inner Mongolia. Cluster b3 came from Yan'an to Yulin. Cluster b4 came from Kaifeng in Henan Province, passing through Zhengzhou, Luoyang, 
374 Yuncheng in Shanxi Province, and Yan'an in Shaanxi Province. In 2019, a total of 492 backward 375 trajectories were divided into three clusters. Cluster c1 to c3 accounted for 16\%, 33\%, and 51\% 376 of total trajectories, respectively. There was a total of 42 pollution trajectories in 2019. Thirty377 two and 10 pollution trajectories were grouped into cluster c2 and c3, respectively. Therefore, 378 the air masses of cluster c2, which came from Linfen in Shanxi and passed through Weinan and 379 Yan'an in Shaanxi Province to Yulin, had the greatest impact on the $\mathrm{O}_{3}$ in Yulin in 2019. Fenwei 380 Plain is to the southeast of Yulin and has 11 cities including Weinan, Luoyang, and Yuncheng,

381

382

383 384

385

386

387

388

389

390

391

392

393

394

395

396

397

398

399

400

401

402

403

404

405

406

407

408

409

410

411

412

413 mentioned above. Fenwei Plain has a high $\mathrm{O}_{3}$ concentration because it has more industry and a larger population (Lu et al., 2019a; Wang et al., 2020a). The airflows from Yan'an and FenWei Plain between May and August may aggravate $\mathrm{O}_{3}$ pollution in Yulin.

\section{Sensitivity analysis}

The relationships between $\mathrm{O}_{3}$ and VOCs and $\mathrm{NO}_{x}$ are nonlinear. In order to establish effective $\mathrm{O}_{3}$ control measures, these relationships must be explored. In this study, we applied two methods to evaluate $\mathrm{O}_{3}-$ VOC-NO $\mathrm{N}_{\mathrm{x}}$ sensitivity in Yulin: the RIR, which was mentioned in Section 2.3, and the EKMA (Carter et al., 1982). The average hourly VOC concentrations during the sampling period were put in the OBM model as a base scenario. By increasing or decreasing the ratio of precursors, we were able to simulate the changes in MDA8 $\mathrm{O}_{3}$. The relationship between MDA8 $\mathrm{O}_{3}$ and the relative changes of anthropogenic VOCs (AVOCs) and $\mathrm{NO}_{\mathrm{x}}$ can be expressed using a contour plot for MDA8 $\mathrm{O}_{3}$, which we named EKMA (Fig. 7a). Isoprene was mainly emitted by the biogenic source and was difficult to control. Therefore, the AVOCs excluded isoprene. The EKMA plot was split into two parts by a ridgeline that denoted the local maxima of the rate of $\mathrm{O}_{3}$ formation ( $\mathrm{Li}$ et al., 2020b; Hui et al., 2018). The upper-left and lower-right areas represent the $\mathrm{O}_{3}$ formation under VOC-limited and $\mathrm{NO}_{\mathrm{x}}$-limited conditions, respectively. In Fig. 7a, the circles and pentagram represent pollution days and the base scenario, respectively. These points were all located in the VOC-limited regime and showed the negative effects of $\mathrm{NO}_{\mathrm{x}}$ reduction in response to $\mathrm{O}_{3}$ production control. Previous studies reported that in China, unban areas, rural regions, and urban agglomerations were under VOC-limited, $\mathrm{NO}_{\mathrm{x}}$-limited, and $\mathrm{VOC}^{-} \mathrm{NO}_{\mathrm{x}}{ }^{-}$ limited conditions (Liu et al., 2019; Wang et al., 2017a), respectively.

Fig.7b shows the RIR values for AVOCs, isoprene, $\mathrm{CO}$, and $\mathrm{NO}_{\mathrm{x}}$ during pollution days. The RIR values for AVOCs were in the range of $0.73-2.83 \% / \%$, which was significantly higher than those for isoprene $(0.22-0.42 \% / \%)$ and $\mathrm{CO}$ (under $0.01 \% / \%)$. This suggested that AVOCs played a more significant role in $\mathrm{O}_{3}$ formation during these EPs, while the influence of isoprene, especially $\mathrm{CO}$, was negligible. Excluding $26 \mathrm{July}$, the RIR values for $\mathrm{NO}_{\mathrm{x}}$ were between -0.26 and $-0.10 \% / \%$, indicating that the $\mathrm{O}_{3}$ formation during these days was in the VOC-limited regime. This result was consistent with that of EKMA. However, on 26 July, the RIR values of $\mathrm{NO}_{\mathrm{x}}$ and VOCs were 0.60 and 0.73 , respectively, and these two positive values with a small difference implied that the $\mathrm{O}_{3}$ formation on 26 July was controlled by both VOCs and $\mathrm{NO}_{\mathrm{x}}$. This result was contrary to that of the EKMA plot, which may be because the EKMA simulation was 
414 based on the average of the sampling period. The average RIR values for AVOCs from EP1 to

415 EP6 were $1.79 \% / \%, 1.92 \% / \%, 1.11 \% / \%, 1.13 \% / \%, 1.34 \% / \%$, and $2.83 \% / \%$, respectively, and 416 for $\mathrm{NO}_{\mathrm{x}}$ were $-0.99 \% / \%, \quad 1.26 \% / \%,-0.14 \% / \%,-0.10 \% / \%,-0.68 \% / \%$, and $-2.36 \% / \%$, 417 respectively. This demonstrated that these EPs were all in the VOC-limited regime. The absolute 418 RIR values of the AVOCs were larger than those of the $\mathrm{NO}_{\mathrm{x}}$, suggesting that $\mathrm{O}_{3}$ formation was 419 most sensitive to AVOC reduction.

420

421

422

\section{$\mathrm{O}_{3}$ control strategies}

423

It is necessary to discuss how much AVOCs should be controlled for the most efficient $\mathrm{O}_{3}$ reduction. Using the sampling period as an example, we will discuss $\mathrm{O}_{3}$ control measures. Fig. 8 a shows the increments of the MDA8 $\mathrm{O}_{3}$ response (positive and negative values represented the increase and decrease in $\mathrm{O}_{3}$ compared to the base case with no $\mathrm{VOC}$ or $\mathrm{NO}_{\mathrm{x}}$ reductions, respectively) to different emission reductions in AVOCs and $\mathrm{NO}_{\mathrm{x}}$ (AVOC reduction $/ \mathrm{NO}_{\mathrm{x}}$ reduction $=1: 2,1: 1,2: 1,3: 1$, or $4: 1$, and only reducing AVOCs or $\mathrm{NO}_{\mathrm{x}}$ ). The horizontal axis represents the combined reduction percentage of AVOCs and $\mathrm{NO}_{\mathrm{x}}$. For instance, a total reduction percentage of $120 \%$ indicates that there were both $60 \%$ reductions in AVOCs and $\mathrm{NO}_{\mathrm{x}}$ emissions for $\mathrm{AVOC} / \mathrm{NO}_{\mathrm{x}}=1: 1$, or $80 \%$ and $40 \%$ reductions in the $\mathrm{AVOC}$ and $\mathrm{NO}_{\mathrm{x}}$ emissions, respectively, for $A V O C / N_{x}=2: 1$. When the $A V O C / N O_{x}$ ratio was more than $1: 1$, namely if the AVOC emission was reduced more than $\mathrm{NO}_{\mathrm{x}}$, the $\mathrm{O}_{3}$ concentration would decline. When a certain $\mathrm{O}_{3}$ reduction target was achieved, the $\mathrm{VOC}$ and $\mathrm{NO}_{\mathrm{x}}$ ratio was higher and the total emission reduction was lower. For example, to reduce $\mathrm{O}_{3}$ concentration by $5 \%$, the total reduction emissions of $\mathrm{AVOC}$ and $\mathrm{NO}_{\mathrm{x}}$ were $12 \%, 20 \%$, and $174 \%$ for an abatement AVOC/NO $\mathrm{Na}_{\mathrm{x}}$ ratio of $4: 1,2: 1$, and $1: 1$, respectively, or by only cutting AVOC emissions by $7 \%$. Only cutting AVOC emissions seemed to be the most efficient way to control $\mathrm{O}_{3}$. However, $\mathrm{NO}_{2}$ is one of the most significant ambient air pollutants that can influence ambient air quality. $\mathrm{NO}_{\mathrm{x}}$ needs to be reduced since it is an important precursor of $\mathrm{PM}_{2.5}$. It is important to cooperatively control the emission of AVOCs and $\mathrm{NO}_{\mathrm{x}}$. During sampling periods, the mean and highest MDA8 $\mathrm{O}_{3}$ concentrations were 79 and 102 ppbv, respectively, which exceeded the Nation Grade II by $5 \%$ and $36 \%$. According to this, we set four $\mathrm{O}_{3}$ control targets, $5 \%, 10 \%, 30 \%$, and $40 \%$, to explore the abatement percentages of AVOCs and $\mathrm{NO}_{x}$ (Fig. 8b). To achieve the $\mathrm{O}_{3}$ control target of 5\%, AVOC emissions needed to be reduced $10 \%-90 \%$, with $\mathrm{NO}_{\mathrm{x}}$ also in the range of $10 \%-90 \%$. To achieve the $\mathrm{O}_{3}$ control target of $10 \%$, AVOC emissions needed to be reduced $20 \%$ to $90 \%$ with $\mathrm{NO}_{\mathrm{x}}$ in the range of $5 \%$ to $80 \%$. However, to achieve the targets of $30 \%$ and $40 \%$, the AVOC emissions needed to be reduced by at least $60 \%$ and $80 \%$, respectively. Even though more stringent $\mathrm{VOC}$ and $\mathrm{NO}_{\mathrm{x}}$ control measures have been implemented, it is still challenging to achieve the $30 \%$ and $40 \% \mathrm{O}_{3}$ control objectives.

$450 \mathrm{Q}_{\text {true }} / \mathrm{Q}_{\text {expected }}$ was an appropriate index to decide how many factors were optimal in the PMF 451 model. Here, we evaluated four to 10 factor solutions and found that the Qtrue/Qexpected values 452 453 of different resolved numbers and that eight to nine factors were the lowest (Fig. S2). Therefore, we identified eight types of major pollution sources using PMF source analysis (Fig. 9 and S3). 
454 Factor 1 had a high percentage of aromatics and a relatively high ratio of toluene. In previous 455 studies, toluene was the most abundant VOC species in painting and factor 1 was considered to 456 be the source of the solvent (Wang et al., 2014). Coking plants and the petrochemical industry 457 are pillars in Yulin and emit a lot of ethene (Zhang et al., 2020c; Han et al., 2018), so we 458 considered factor 2 to be industrial sources. The main source of isoprene in the city is plant 459 emissions (Zhang et al., 2020a; Loivamaki et al., 2007) and factor 3 is considered a biological 460 source. Factor 4 was characterized by a high percentage of ethane and high loadings of OVOCs. 461 Previous studies in Shenzhen and Wangdu found that background pollution largely contributed 462 to OVOCs (Han et al., 2019). Factor 4 was considered background pollution. High percentages 463 of propane, acetylene, n-butane, cyclohexane, ethylbenzene, o-xylene, isobutane, m/p-xylene, 464 and n-hexane are found in vehicle exhaust (Fan et al., 2020), and these characteristics are 465 consistent with factors 5 and 7. The proportion of isopentane in gasoline exhaust is more than

466

467

468

469

470

471

472

473

474

475

476

477

478

479

480

481

482

483

484

485

486

487

488

489

490

491

492

493

that found in diesel exhaust (Ly et al., 2020). The proportion of aromatic hydrocarbons is higher in gasoline vehicles than in diesel vehicles because aromatic hydrocarbons are the main contributor to octane in gasoline, and gasoline is more volatile than diesel (Huang et al., 2020). Factors 5 and 7 were considered gasoline exhaust and diesel exhaust, respectively. Isopentane is mainly distributed in factor 6 and is a typical marker of fuel evaporation (Liu et al., 2008), so factor 6 was considered fuel evaporation. Factor 8 was characterized by a high percentage of ethane, ethene, and 1-butene. Previous studies reported that VOCs emitted from coal combustion (Zhang et al., 2020a) are mainly C2-C3 alkenes and C2-C3 alkanes. Factor 7 was considered coal combustion. Vehicle emissions count for $51.1 \%$ of emissions (Fig. 9) and diesel exhaust is most dominant. Industrial sources account for $17.0 \%$. Previous emission reduction strategies focused on reducing vehicle and industry emissions, especially diesel exhaust.

\section{Conclusion}

We measured ambient $\mathrm{O}_{3}$ levels at four National Environmental Monitoring Stations. The MDA8 90th $\mathrm{O}_{3}$ concentrations in Yulin were 72, 72, and 75 ppbv from 2017 to 2019, respectively, and they showed an increasing trend. The EMB site had the highest $\mathrm{O}_{3}$ levels. Because the HPGP site is a traffic-intensive area, this site had more NO emissions from trucks during night transportation that led to lower night concentrations than at the other sites. $\mathrm{O}_{3}$ concentrations were higher in summer and lower in winter, reflecting an obvious seasonal cycle, and the pollution days occurred between May and August.

Our $\mathrm{O}_{3}$ and $\mathrm{T}, \mathrm{RH}$, and WS correlation analysis results implied that $\mathrm{O}_{3}$ had a positive correlation with $\mathrm{T}$ and a negative correlation with $\mathrm{RH}$. Through statistical analysis, we found that when $\mathrm{T}$ was greater than $25^{\circ} \mathrm{C}$, RH was lower than $60 \%$, WS was less than $3 \mathrm{~m} / \mathrm{s}$, and the WD was northerly, the probability of MDA8 $\mathrm{O}_{3}$ exceeding the Grade II Standard increased. Using the HYSPLIT model to calculate the backward trajectories from May to August 2017 to 2019, we saw that the $\mathrm{O}_{3}$ concentration in summer was greatly affected by transportation on the Fenwei Plain.

Peer) reviewing PDF | (2021:01:57042:1:1:NEW 24 Mar 2021) 
494

495

496

497

498

499

500

501

502

503

504

505

506

507

508

509

\section{0}

511

512

513

514

515

516

517

518

519

520

521

522

523

524

525

526

527

528

529

530

531

532

533

534

535

536

537

The VOC sampling period from July 7th to August 10 th had $13 \mathrm{O}_{3}$ pollution days across six EPs. During this period, the average $\mathrm{O}_{3}$ and TVOCs were $50 \pm 22 \mathrm{ppbv}$ and $26 \pm 12 \mathrm{ppbv}$, respectively. Alkane was the most abundant VOC group. As a result of the OFP and $\mathrm{OH}$ reaction, alkenes were the most important VOC species for $\mathrm{O}_{3}$ formation. Using the OBMcalculated EKMA plot and RIR value indicated that Yulin is located in a VOC-limited regime. This suggested that a slight decrease of $\mathrm{NO}_{x}$ may increase $\mathrm{O}_{3}$ concentration. The AVOC RIR value was the highest and was the key VOC that needed to be primarily controlled. In regard to $\mathrm{O}_{3}$ control strategies, when the reduction of $A V O C / \mathrm{NO}_{x}$ is higher than $1: 1$, the $\mathrm{O}_{3}$ will decrease. According to the average and maximum MDA8 $\mathrm{O}_{3}$, we set four targets for decreased $\mathrm{O}_{3}$ emissions. For $\mathrm{O}_{3}$ concentrations to decrease by 5\%, AVOCs and $\mathrm{NO}_{\mathrm{x}}$ are needed to reduce emissions by $10 \%-90 \%$. For $\mathrm{O}_{3}$ concentrations to decrease by $10 \%$, AVOCs and $\mathrm{NO}_{\mathrm{x}}$ are needed to reduce emissions by $20 \%-90 \%$ and $5 \%-80 \%$, respectively. However, the $30 \%$ and $40 \%$ targets will be difficult to achieve. The PMF model showed that vehicle exhaust and coal chemical industry emissions are the main sources of AVOC emission reductions.

\section{Acknowledgements}

We sincerely thank Zhen He from Guizhou University, and Fang Bi, Zhenhai Wu, and Yujie Zhang from the Chinese Research Academy of Environmental Sciences for their great help. We would also like to thank the reviewers and editors who contributed valuable comments to improve the quality of this paper.

\section{References}

Atkinson R. 1990. Gas-phase tropospheric chemistry of organic compounds: A review. Atmospheric Environment Part A General Topics 24:1-41. DOI:https://doi.org/10.1016/0960-1686(90)90438-S.

Atkinson R, and Arey J. 2004. Atmospheric Degradation of Volatile Organic Compounds. Chemical reviews 103:4605-4638. DOI:http://doi.org/10.1021/cr0206420.

Cao JJ, Chow JC, Watson JG, Wu F, Han YM, Jin ZD, Shen ZX, and An ZS. 2008a. Sizedifferentiated source profiles for fugitive dust in the Chinese Loess Plateau. Atmospheric Environment 42:2261-2275. DOI:https://doi.org/10.1016/j.atmosenv.2007.12.041.

Cao JJ, Shen ZX, Chow JC, Watson JG, Lee SC, Tie XX, Ho KF, Wang GH, and Han YM. 2012. Winter and Summer PM2.5 Chemical Compositions in Fourteen Chinese Cities. Journal of the Air \& Waste Management Association 62:1214-1226. DOI:https://doi.org/10.1080/10962247.2012.701193.

Cao JJ, Zhu CS, Chow JC, Liu WG, Han YM, and Watson JG. 2008b. Stable carbon and oxygen isotopic composition of carbonate in fugitive dust in the Chinese Loess Plateau. Atmospheric Environment DOI:https://doi.org/10.1016/j.atmosenv.2008.09.043.

42:9118-9122.

Cardelino CA, and Chameides WL. 1995. An observation-based model for analyzing ozone precursor relationships in the urban atmosphere. J Air Waste Manag Assoc 45:161-180. DOI:https://doi.org/10.1080/10473289.1995.10467356.

Carter WP, Winer AM, and Pitts Jr JN. 1982. Effects of kinetic mechanisms and hydrocarbon composition on oxidant-precursor relationships predicted by the EKMA isopleth 
538

539

540

541

542

543

544

545

546

547

548

549

550

551

552

553

554

555

556

557

558

559

560

561

562

563

564

565

566

567

568

569

570

571

572

573

574

575

576

577

578

579

580

581

582

583

584

585

586

587

588

technique. Atmospheric Environment 16:113-120. DOI:https://doi.org/10.1016/00046981(82)90318-3.

Carter WPL. 2009. Updated Maximum Incremental Reactivity Scale and Hydrocarbon Bin Reactivities for Regulatory Applications. California Air Resources Board Contract.

Chen X, Situ S, Zhang Q, Wang X, Sha C, Zhouc L, Wu L, Wu L, Ye L, and Li C. 2019. The synergetic control of $\mathrm{NO} 2$ and $\mathrm{O} 3$ concentrations in a manufacturing city of southern China. Atmospheric Environment 201:402-416. DOI:https://doi.org/10.1016/j.atmosenv.2018.12.021.

Chen Z, Li R, Chen D, Zhuang Y, Gao B, Yang L, and Li M. 2020. Understanding the causal influence of major meteorological factors on ground ozone concentrations across China. Journal of Cleaner Production 242. DOl:http://doi.org/10.1016/j.jclepro.2019.118498.

Cohen MD, Stunder BJB, Rolph GD, Draxler RR, Stein AF, and Ngan F. 2015. NOAA's HYSPLIT Atmospheric Transport and Dispersion Modeling System. Bulletin of the American Meteorological Society 96:2059-2077. DOI:https://doi.org/10.1175/bams-d-1400110.1.

Crutzen PJ. 2016. Photochemical reactions initiated by and influencing ozone in unpolluted tropospheric air. Tellus 26:47-57. DOl:http://doi.org/10.3402/tellusa.v26i1-2.9736.

David LM, and Nair PR. 2011. Diurnal and seasonal variability of surface ozone and NOxat a tropical coastal site: Association with mesoscale and synoptic meteorological conditions. Journal of Geophysical Research 116. DOI:http://doi.org/10.1029/2010jd015076.

Dawson JP, Adams PJ, and Pandis SN. 2007. Sensitivity of ozone to summertime climate in the eastern USA: A modeling case study. Atmospheric Environment 41:1494-1511. DOI:http://doi.org/10.1016/j.atmosenv.2006.10.033.

Draxler RR, and Hess GD. 1998. An overview of the HYSPLIT_4 modeling system for trajectories, dispersion, and deposition. Australian Meteorological Magazine 47.

Duan J, Tan J, Yang L, Wu S, and Hao J. 2008. Concentration, sources and ozone formation potential of volatile organic compounds (VOCs) during ozone episode in Beijing. Atmospheric Research 88:25-35. DOI:https://doi.org/10.1016/j.atmosres.2007.09.004.

Fan M-Y, Zhang Y-L, Lin Y-C, Li L, Xie F, Hu J, Mozaffar A, and Cao F. 2020. Source apportionments of atmospheric volatile organic compounds in Nanjing, China during high $\begin{array}{llll}\text { ozone pollution } & \text { Season. }\end{array}$ DOI:http://doi.org/10.1016/j.chemosphere.2020.128025.

Fang X, Xiao H, Sun H, Liu C, Zhang Z, Xie Y, Liang Y, and Wang F. 2020. Characteristics of Ground-Level Ozone from 2015 to 2018 in BTH Area, China. Atmosphere 11:130. DOI:https://doi.org/10.3390/atmos11020130.

Han D, Gao S, Fu Q, Cheng J, Chen X, Xu H, Liang S, Zhou Y, and Ma Y. 2018. Do volatile organic compounds (VOCs) emitted from petrochemical industries affect regional PM2.5? Atmospheric Research 209:123-130. DOI:https://doi.org/10.1016/j.atmosres.2018.04.002.

Han Y, Huang X, Wang C, Zhu B, and He L. 2019. Characterizing oxygenated volatile organic compounds and their sources in rural atmospheres in China. Journal of the Electrochemical Society 81:148-155. DOI:https://doi.org/10.1016/j.jes.2019.01.017.

Hao X, Song M, Feng Y, and Zhang W. 2019. De-Capacity Policy Effect on China's Coal Industry. Energies 12. DOI:https://doi.org/10.3390/en12122331.

He Z, Wang X, Ling Z, Zhao J, and Wang Z. 2019. Contributions of different anthropogenic volatile organic compound sources to ozone formation at a receptor site in the Pearl River Delta region and its policy implications. Atmospheric Chemistry Physics 19:88018816. DOI:https://doi.org/10.5194/acp-19-8801-2019.

He Z, Zhang X, Li Y, Zhong X, Li H, Gao R, and Li J. 2020. Characterizing carbonyl compounds and their sources in Fuzhou ambient air, southeast of China. Peerj. DOI:http://doi.org/10.7717/peerj.10227. 
589

590

591

592

593

594

595

596

597

598

599

600

601

602

603

604

605

606

607

608

609

610

611

612

613

614

615

616

617

618

619

620

621

622

623

624

625

626

627

628

629

630

631

632

633

634

635

636

637

638

Hou X, Zhuang G, Sun Y, and An Z. 2006. Characteristics and sources of polycyclic aromatic hydrocarbons and fatty acids in PM2.5 aerosols in dust season in China. Atmospheric Environment 40:3251-3262. DOI:https://doi.org/10.1016/j.atmosenv.2006.02.003.

Hu XM, Ma Z, Lin W, Zhang H, Hu J, Wang Y, Xu X, Fuentes JD, and Xue M. 2014. Impact of the Loess Plateau on the atmospheric boundary layer structure and air quality in the North China Plain: a case study. Science of the Total Environ 499:228-237. DOI:https://doi.org/10.1016/j.scitotenv.2014.08.053.

Huang $\mathrm{H}$, Hu H, Zhang J, and Liu X. 2020. Characteristics of volatile organic compounds from vehicle emissions through on-road test in Wuhan, China. Environmental Research 188:109802. DOl:https://doi.org/10.1016/j.envres.2020.109802.

Hui L, Liu X, Tan Q, Feng M, An J, Qu Y, Zhang Y, Deng Y, Zhai R, and Wang Z. 2020. VOC characteristics, chemical reactivity and sources in urban Wuhan, central China. Atmospheric Environment 224. DOI:10.1016/j.atmosenv.2020.117340.

Hui L, Liu X, Tan Q, Feng M, An J, Qu Y, Zhang Y, and Jiang M. 2018. Characteristics, source apportionment and contribution of VOCs to ozone formation in Wuhan, Central China. Atmospheric Environment 192:55-71. DOI:http://doi.org/10.1016/j.atmosenv.2018.08.042.

Hui L, Ma T, Gao Z, Gao J, Wang Z, Xue L, Liu H, and Liu J. 2021. Characteristics and sources of volatile organic compounds during high ozone episodes: A case study at a site in the eastern Guanzhong Plain, China. Chemosphere 265:129072. DOI:http://10.1016/j.chemosphere.2020.129072.

Kavassalis SC, and Murphy JG. 2017. Understanding ozone-meteorology correlations: A role for dry deposition. Geophysical Research Letters 44:2922-2931. DOI:http://doi.org/10.1002/2016gl071791.

Lei Y, Shen Z, Wang Q, Zhang T, Cao J, Sun J, Zhang Q, Wang L, Xu H, and Tian JJAr. 2018. Optical characteristics and source apportionment of brown carbon in winter PM_(2.5) over Yulin in Northern China. 213:27-33.

Li B, Zhou Z, Xue Z, Wei P, Ren Y, Cao L, Feng X, Yao Q, Ma J, Xu P, and Chen X. 2020a. Study on the Pollution Characteristics and Sources of Ozone in Typical Loess Plateau City. Atmosphere 11. DOl:http://doi.org/10.3390/atmos11060555.

Li J, Wang Z, Chen L, Lian L, Li Y, Zhao L, Zhou S, Mao X, Huang T, Gao H, and Ma J. 2020b. WRF-Chem simulations of ozone pollution and control strategy in petrochemical industrialized and heavily polluted Lanzhou City, Northwestern China. Science of the Total Environ 737:139835. DOl:https://doi.org/10.1016/j.scitotenv.2020.139835.

Li J, Zhao Y, Han L, Zhang G, and Liu R. 2017. Moisture variation inferred from a nebkha profile correlates with vegetation changes in the southwestern Mu Us Desert of China over one century. Science of The Total Environment 598:797-804. DOI:https://doi.org/10.1016/j.scitotenv.2017.03.145.

Li K, Jacob DJ, Shen L, Lu X, De Smedt I, and Liao H. 2020c. Increases in surface ozone pollution in China from 2013 to 2019: anthropogenic and meteorological influences. Atmospheric Chemistry and Physics 20:11423-11433. DOl:http://doi.org/10.5194/acp20-11423-2020.

Li L, An J, Huang L, Yan R, Huang C, and Yarwood G. 2019. Ozone source apportionment over the Yangtze River Delta region, China: Investigation of regional transport, sectoral contributions and seasonal differences. Atmospheric Environment 202:269-280. DOI:https://doi.org/10.1016/j.atmosenv.2019.01.028.

Liu LY, Shi PJ, Gao SY, Zou XY, Erdon H, Yan P, Li XY, Ta WQ, Wang JH, and Zhang CL. 2004. Dustfall in China's western loess plateau as influenced by dust storm and haze events. Atmospheric Environment DOI:https://doi.org/10.1016/j.atmosenv.2004.01.003.

Peer) reviewing PDF | (2021:01:57042:1:1:NEW 24 Mar 2021) 
639 Liu N, Lin W, Ma J, Xu W, and $\mathbf{X u ~ X . ~ 2 0 1 9 . ~ S e a s o n a l ~ v a r i a t i o n ~ i n ~ s u r f a c e ~ o z o n e ~ a n d ~ i t s ~}$

640

641

642

643

644

645

646

647

648

649

650

651

652

653

654

655

656

657

658

659

660

661

662

663

664

665

666

667

668

669

670

671

672

673

674

675

676

677

678

679

680

681

682

683

684

685

686

687

688

689 regional characteristics at global atmosphere watch stations in China. Journal of Environmental Sciences 77:291-302. DOI:https://doi.org/10.1016/j.jes.2018.08.009.

Liu Y, Shao M, Fu L, Lu S, Zeng L, and Tang D. 2008. Source profiles of volatile organic compounds (VOCs) measured in China: Part I. Atmospheric Environment 42:6247-6260. DOI:https://doi.org/10.1016/j.atmosenv.2008.01.070.

Liu Y, and Wang T. 2020. Worsening urban ozone pollution in China from 2013 to 2017 Part 1: The complex and varying roles of meteorology. Atmospheric Chemistry and Physics 20:6305-6321. DOI:http://doi.org/10.5194/acp-20-6305-2020.

Loivamaki M, Gilmer F, Fischbach RJ, Sorgel C, Bachl A, Walter A, and Schnitzler JP. 2007. Arabidopsis, a model to study biological functions of isoprene emission? Plant Physiol 144:1066-1078. DOI:https://doi.org/10.1104/pp.107.098509.

Lu X, Zhang L, Chen Y, Zhou M, Zheng B, Li K, Liu Y, Lin J, Fu T-M, and Zhang Q. 2019a. Exploring 2016-2017 surface ozone pollution over China: source contributions and meteorological influences. Atmospheric Chemistry and Physics 19:8339-8361. DOI:http://doi.org/10.5194/acp-19-8339-2019.

Lu X, Zhang L, and Shen L. 2019b. Meteorology and Climate Influences on Tropospheric Ozone: a Review of Natural Sources, Chemistry, and Transport Patterns. Current Pollution Reports 5:238-260. DOI:http://doi.org/10.1007/s40726-019-00118-3.

Ly BT, Kajii Y, Nguyen TY, Shoji K, Van DA, Do TN, Nghiem TD, and Sakamoto Y. 2020. Characteristics of roadside volatile organic compounds in an urban area dominated by gasoline vehicles, a case study in Hanoi. Chemosphere 254:126749. DOI:https://doi.org/10.1016/j.chemosphere.2020.126749.

Lyu X, Wang N, Guo H, Xue L, Jiang F, Zeren Y, Cheng H, Cai Z, Han L, and Zhou Y. 2019. Causes of a continuous summertime O\&lt;sub\&gt;3\&lt;/sub\&gt; pollution event in Jinan, a central city in the North China Plain. Atmospheric Chemistry and Physics 19:30253042. DOI:10.5194/acp-19-3025-2019.

Paatero P, and Tapper U. 1994. Positive matrix factorization: A non-negative factor model with optimal utilization of error estimates of data values. 5:111-126. DOI:https://doi.org/10.1002/env.3170050203.

Song M, Li X, Yang S, Yu X, Zhou S, Yang Y, Chen S, Dong H, Liao K, Chen Q, Lu K, Zhang N, Cao J, Zeng L, and Zhang Y. 2020. Spatiotemporal Variation, Sources, and Secondary Transformation Potential of VOCs in Xi'an, China. Atmospheric Chemistry Physics. DOI:http://doi.org/10.5194/acp-2020-704.

Sun X, Wang H, Guo Z, Lu P, Song F, Liu L, Liu J, Rose NL, and Wang F. 2020. Positive matrix factorization on source apportionment for typical pollutants in different environmental media: a review. Environ Sci Process Impacts 22:239-255. DOI:http://doi.org/10.1039/c9em00529c.

Tan Z, Lu K, Jiang M, Su R, Dong H, Zeng L, Xie S, Tan Q, and Zhang Y. 2018. Exploring ozone pollution in Chengdu, southwestern China: A case study from radical chemistry to O3-VOC-NOx sensitivity. Science of the Total Environ 636:775-786. DOI:http://doi.org/10.1016/j.scitotenv.2018.04.286.

Tan Z, Lu K, Jiang M, Su R, and Zhang Y. 2019. Daytime atmospheric oxidation capacity in four Chinese megacities during the photochemically polluted season: A case study based on box model simulation. Atmospheric Chemistry Physics

19:3493-3513. DOl:https://doi.org/10.5194/acp-19-3493-2019.

Wang F, Qiu X, Cao J, Peng L, Zhang N, Yan Y, and Li R. 2020a. Policy-driven changes in the health risk of PM2.5 and O3 exposure in China during 2013-2018. Science of The Total Environment. DOI:http://doi.org/10.1016/j.scitotenv.2020.143775.

Wang H, Qiao Y, Chen C, Lu J, Dai H, Qiao L, Lou S, Huang C, Li L, Jing S, and Wu J. 2014. Source Profiles and Chemical Reactivity of Volatile Organic Compounds from

Peer) reviewing PDF | (2021:01:57042:1:1:NEW 24 Mar 2021) 
690

691

692

693

694

695

696

697

698

699

700

701

702

703

704

705

706

707

708

709

710

711

712

713

714

715

716

717

718

719

720

721

722

723

724

725

726

727

728

729

730

731

732

733

734

735

736

737

738

739

740

Solvent Use in Shanghai, China. Aerosol and Air Quality Research 14:301-310. DOI:https://doi.org/10.4209/aaqr.2013.03.0064.

Wang M, Chen W, Zhang L, Qin W, Zhang Y, Zhang X, and Xie X. 2020b. Ozone pollution characteristics and sensitivity analysis using an observation-based model in Nanjing, Yangtze River Delta Region of China. Journal of Environmental Sciences 93:13-22. DOI:http://doi.org/10.1016/j.jes.2020.02.027.

Wang Q, Zhuang G, Li J, Huang K, Zhang R, Jiang Y, Lin Y, and Fu JS. 2011. Mixing of dust with pollution on the transport path of Asian dust--revealed from the aerosol over Yulin, the north edge of Loess Plateau. Science of The Total Environment 409:573-581. DOI:https://doi.org/10.1016/j.scitotenv.2010.10.032.

Wang T, Xue L, Brimblecombe P, Lam YF, Li L, and Zhang L. 2017a. Ozone pollution in China: A review of concentrations, meteorological influences, chemical precursors, and effects. Science of the Total Environ 575:1582-1596. DOI:https://doi.org/10.1016/j.scitotenv.2016.10.081.

Wang WN, Cheng TH, Gu XF, Chen H, Guo H, Wang Y, Bao FW, Shi SY, Xu BR, Zuo X, Meng C, and Zhang XC. 2017b. Assessing Spatial and Temporal Patterns of Observed Ground-level Ozone in China. Sci Rep 7:3651. DOI:http://doi.org/10.1038/s41598-01703929-w.

Wang X, Shen Z, Cao J, Zhang L, Liu L, Li J, Liu S, and Sun Y. 2012. Characteristics of surface ozone at an urban site of Xi'an in Northwest China. Journal of Environmental Monitoring 14:116-126. DOI:http://doi.org/10.1039/c1em10541h.

Wu Y, Hu J, Wang H, Li H, Zhang H, Chai F, and Wang S. 2019. The Characteristics of Ambient Non-Methane Hydrocarbons (NMHCs) in Lanzhou, China. Atmosphere 10. DOI:https://doi.org/10.3390/atmos10120745.

Xiaoye Z. 2002. Characterization of Atmospheric Aerosol over XiAn in the South Margin of the Loess Plateau, China. Atmospheric Environment 36:4189-4199. DOI:https://doi.org/10.1016/S1352-2310(02)00347-3.

Xu J, Ma JZ, Zhang XL, Xu XB, Xu XF, Lin WL, Wang Y, Meng W, and Ma ZQ. 2011. Measurements of ozone and its precursors in Beijing during summertime: impact of urban plumes on ozone pollution in downwind rural areas. Atmospheric Chemistry and Physics 11:12241-12252. DOI:https://doi.org/10.5194/acp-11-12241-2011.

Yan C, Nie W, Äijälä M, Rissanen MP, Canagaratna MR, Massoli P, Junninen H, Jokinen T, Sarnela N, Häme S, Schobesberger S, Canonaco F, Prevot ASH, Petäjä T, Kulmala M, Sipilä M, Worsnop DR, and Ehn M. 2016a. Source characterization of highly oxidized multifunctional compounds in a boreal forest environment using positive matrix factorization. Atmospheric Chemistry and Physics:1680-7316. DOI:https://doi.org/10.5194/acp-16-12715-2016.

Yan S, Cao H, Chen Y, Wu C, Hong T, and Fan H. 2016b. Spatial and temporal characteristics of air quality and air pollutants in 2013 in Beijing. Environ Sci Pollut Res Int 23:1399614007. DOI:https://doi.org/10.1007/s11356-016-6518-3.

Yu D, Tan Z, Lu K, Ma X, Li X, Chen S, Zhu B, Lin L, Li Y, Qiu P, Yang X, Liu Y, Wang H, He L, Huang $X$, and Zhang Y. 2020a. An explicit study of local ozone budget and NOxVOCs sensitivity in Shenzhen China. Atmospheric Environment 224. DOI:http://doi.org/10.1016/j.atmosenv.2020.117304.

Yu S, Yin S, Zhang R, Wang L, Su F, Zhang Y, and Yang J. 2020b. Spatiotemporal characterization and regional contributions of $\mathrm{O} 3$ and NO2: An investigation of two years of monitoring data in Henan, China. Journal of Environmental Sciences 90:29-40. DOI:http://doi.org/10.1016/j.jes.2019.10.012.

Zeng Y, Cao Y, Qiao X, Seyler BC, and Tang Y. 2019. Air pollution reduction in China: Recent success but great challenge for the future. Science of the Total Environ 663:329-337. DOI:https://doi.org/10.1016/j.scitotenv.2019.01.262. 
741

742

743

744

745

746

747

748

749

750

751

752

753

754

755

756

757

758

759

760

761

762

763

764

765

766

767

768

769

770

771

772

773

Zhai X, Cheng Z, Chang S, Ai X, and Zhang X. 2020. An analysis on the current situation of energy development and its environmental problems in Yulin City. Energy Reports 6:1520. DOI:https://doi.org/10.1016/j.egyr.2019.08.011.

Zhang F, Shang X, Chen H, Xie G, Fu Y, Wu D, Sun W, Liu P, Zhang C, Mu Y, Zeng L, Wan M, Wang Y, Xiao H, Wang G, and Chen J. 2020a. Significant impact of coal combustion on VOCs emissions in winter in a North China rural site. Science of the Total Environ 720:137617. DOI:https://doi.org/10.1016/j.scitotenv.2020.137617.

Zhang K, Li L, Huang L, Wang Y, Huo J, Duan Y, Wang Y, and Fu Q. 2020b. The impact of volatile organic compounds on ozone formation in the suburban area of Shanghai. Atmospheric Environment 232. DOI:http://doi.org/10.1016/j.atmosenv.2020.117511.

Zhang Q, Shen Z, Cao J, Ho K, Zhang R, Bie Z, Chang H, and Liu S. 2014a. Chemical profiles of urban fugitive dust over Xi'an in the south margin of the Loess Plateau, China. Atmospheric Pollution Research 5:421-430. DOI:https://doi.org/10.5094/apr.2014.049.

Zhang Q, Yuan B, Shao M, Wang X, Lu S, Lu K, Wang M, Chen L, Chang CC, and Liu SC. 2014b. Variations of ground-level $\mathrm{O} 3$ and its precursors in Beijing in summertime between 2005 and 2011. Atmospheric Chemistry and Physics 14:6089-6101. DOI:https://doi.org/10.5194/acp-14-6089-2014.

Zhang Q, Zheng Y, Tong D, Shao M, Wang S, Zhang Y, Xu X, Wang J, He H, Liu W, Ding Y, Lei Y, Li J, Wang Z, Zhang X, Wang Y, Cheng J, Liu Y, Shi Q, Yan L, Geng G, Hong C, Li M, Liu F, Zheng B, Cao J, Ding A, Gao J, Fu Q, Huo J, Liu B, Liu Z, Yang F, He K, and Hao J. 2019. Drivers of improved PM2.5 air quality in China from 2013 to 2017. PNAS 116:24463-24469. DOI:https://doi.org/10.1073/pnas.1907956116.

Zhang X, Wang D, Liu Y, Cui Y, Xue Z, Gao Z, and Du J. 2020c. Characteristics and ozone formation potential of volatile organic compounds in emissions from a typical Chinese coking plant. Journal of Environmental Sciences 95:183-189. DOI:https://doi.org/10.1016/j.jes.2020.03.018.

Zheng D, Wang Y, Shao Y, and Wang L. 2019. The Vegetation Dynamics and Climate Change Responses by Leaf Area Index in the Mu Us Desert. Sustainability 11. DOI:http://doi.org/10.3390/su11113151.

Zhu Y, Yan X, Kong X, Tong Q, Li Y, Huang G, and Li Y. 2019. Industry-environment system management based on an uncertain Gaussian diffusion optimization model for coaldependent cities in ecologically fragile areas. Journal of Cleaner Production 234:832857. DOI:https://doi.org/10.1016/j.jclepro.2019.06.142.

Peer] reviewing PDF | (2021:01:57042:1:1:NEW 24 Mar 2021) 
Figure 1

Locations of four National Environmental Monitoring Stations (HGEP, CS, EMS and EMB).

(Map data $\odot 2020$ Google Earth)

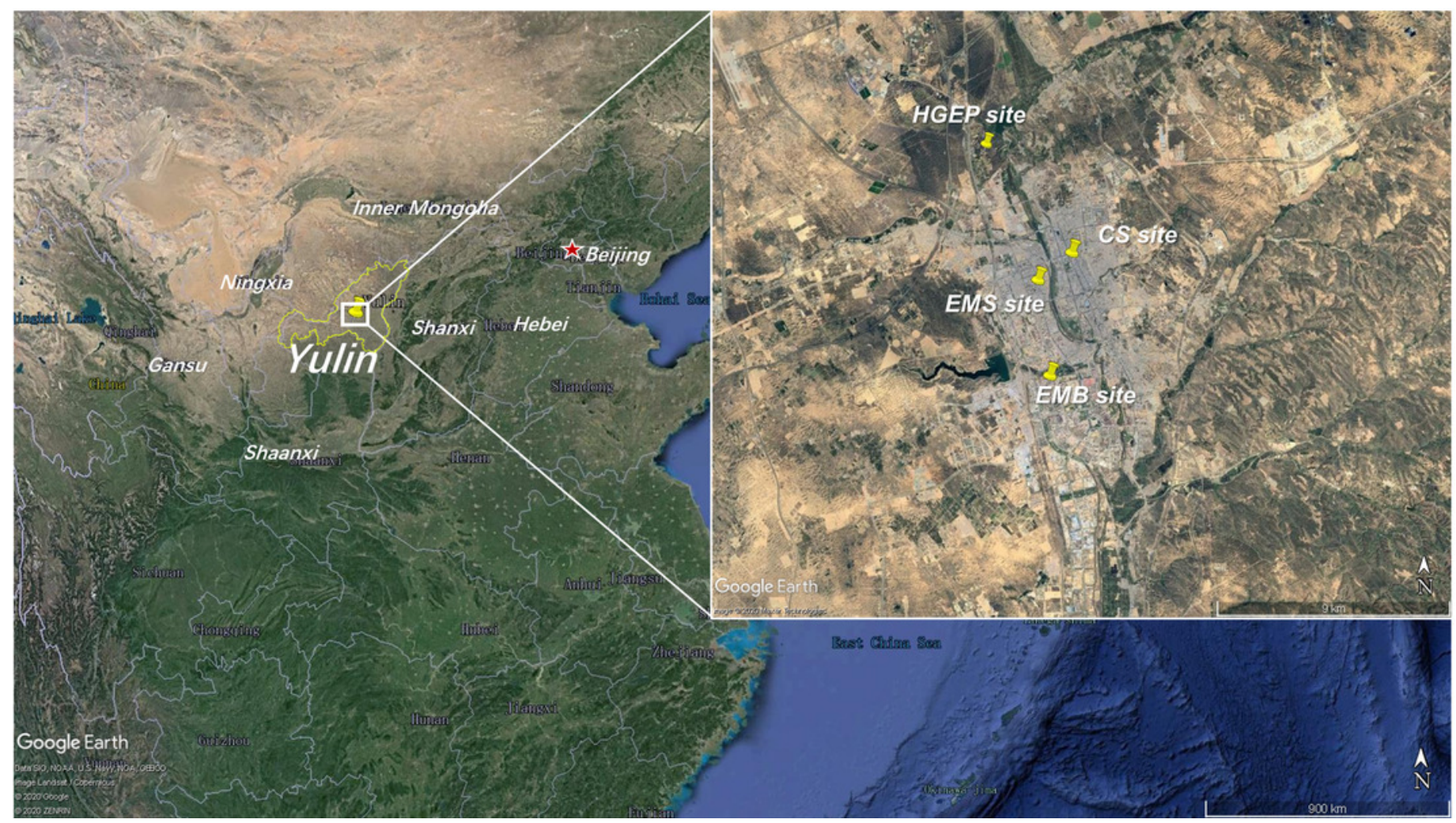


Figure 2

(a) Monthly variation of MDA8-90 $\mathrm{O}_{3}$ concentrations, (b) diurnal variation of 1-hour average $\mathrm{O}_{3}$ concentrations.

(a)

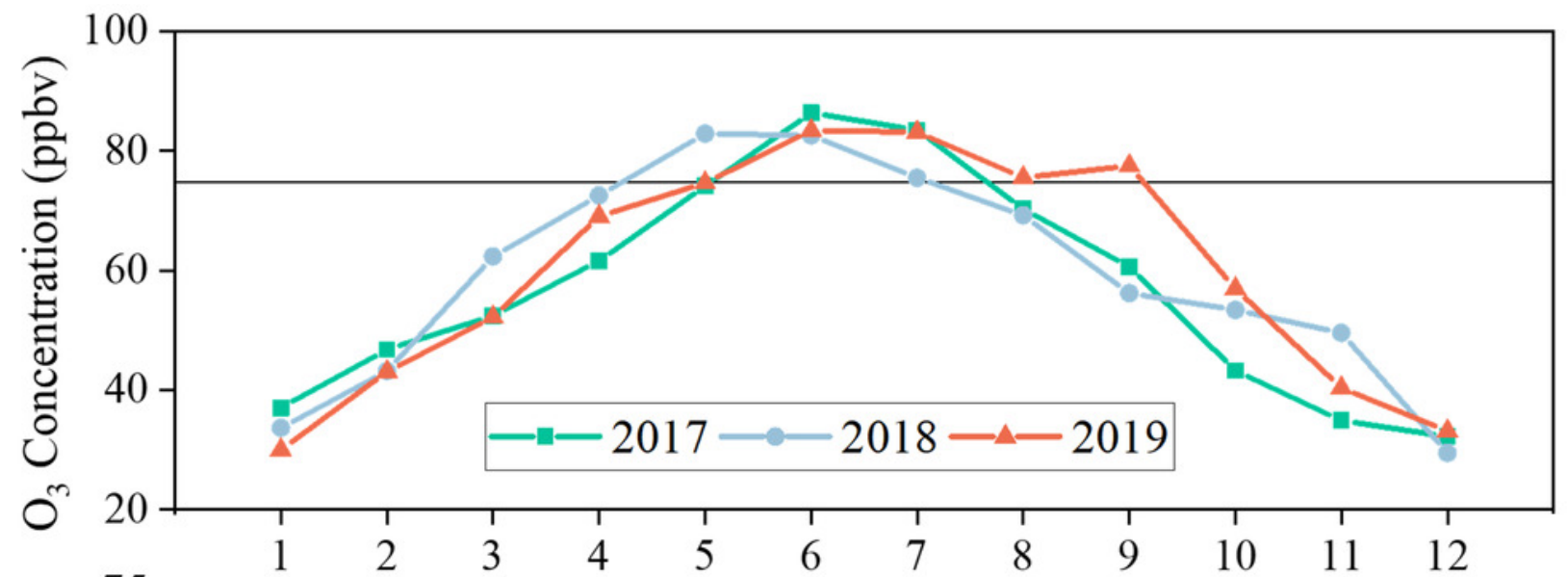

(b)

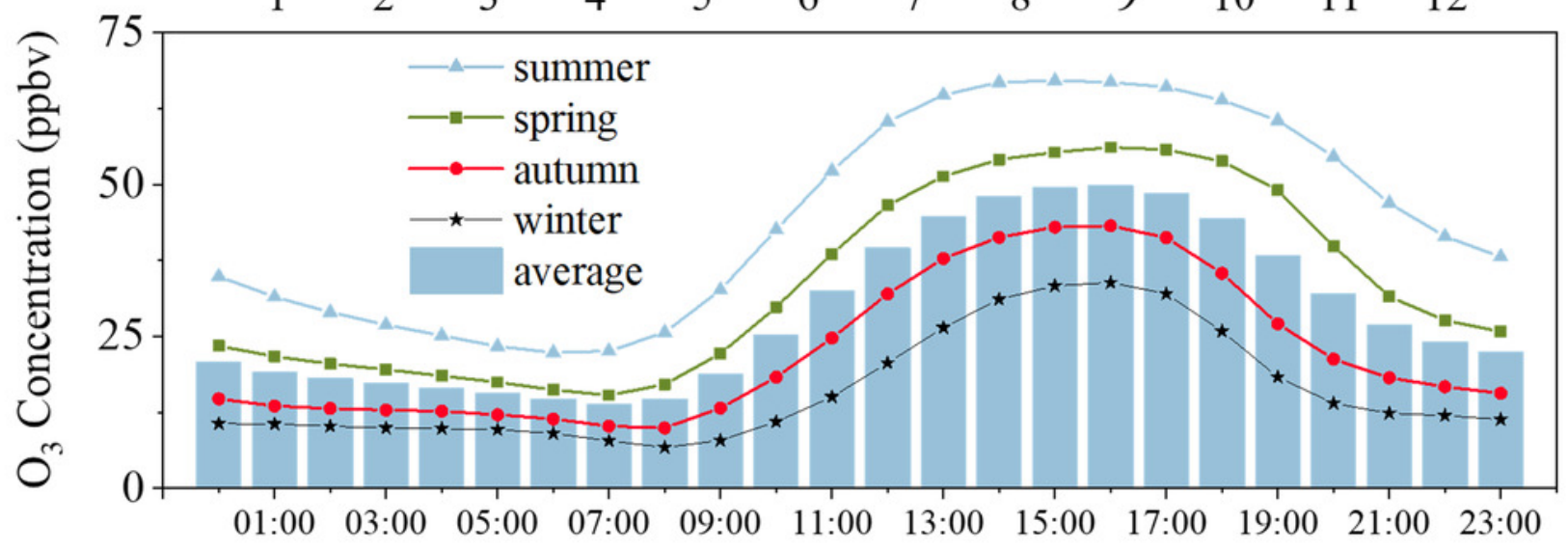


Figure 3

$\mathrm{O}_{3}$ concentrations distributed at four sites in Yulin from 2017 to 2019.

In each box plot, the block is the mean, the horizontal line crossing the box is the median, the bottom and top of the box are lower and upper quartiles, and the whiskers are the $10^{\text {th }}$ percentile and $90^{\text {th }}$ percentile.

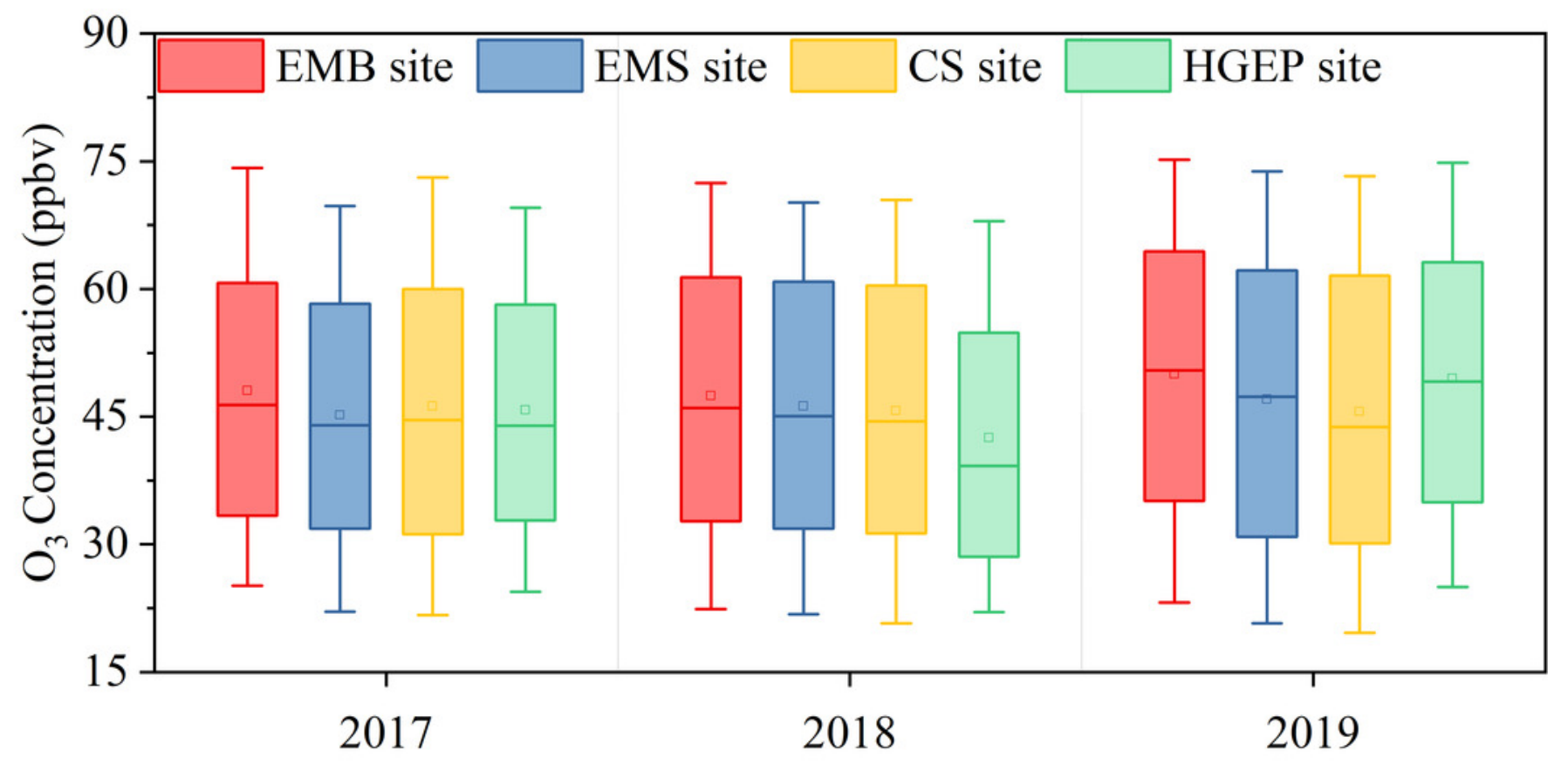


Figure 4

Time series of WS, WD, $\mathrm{T}, \mathrm{RH}, \mathrm{O}_{3}, \mathrm{PM}_{2.5}, \mathrm{PM}_{10}, \mathrm{NO}_{2}, \mathrm{CO}$ and VOCs at the EMB site during VOCs sampling period.

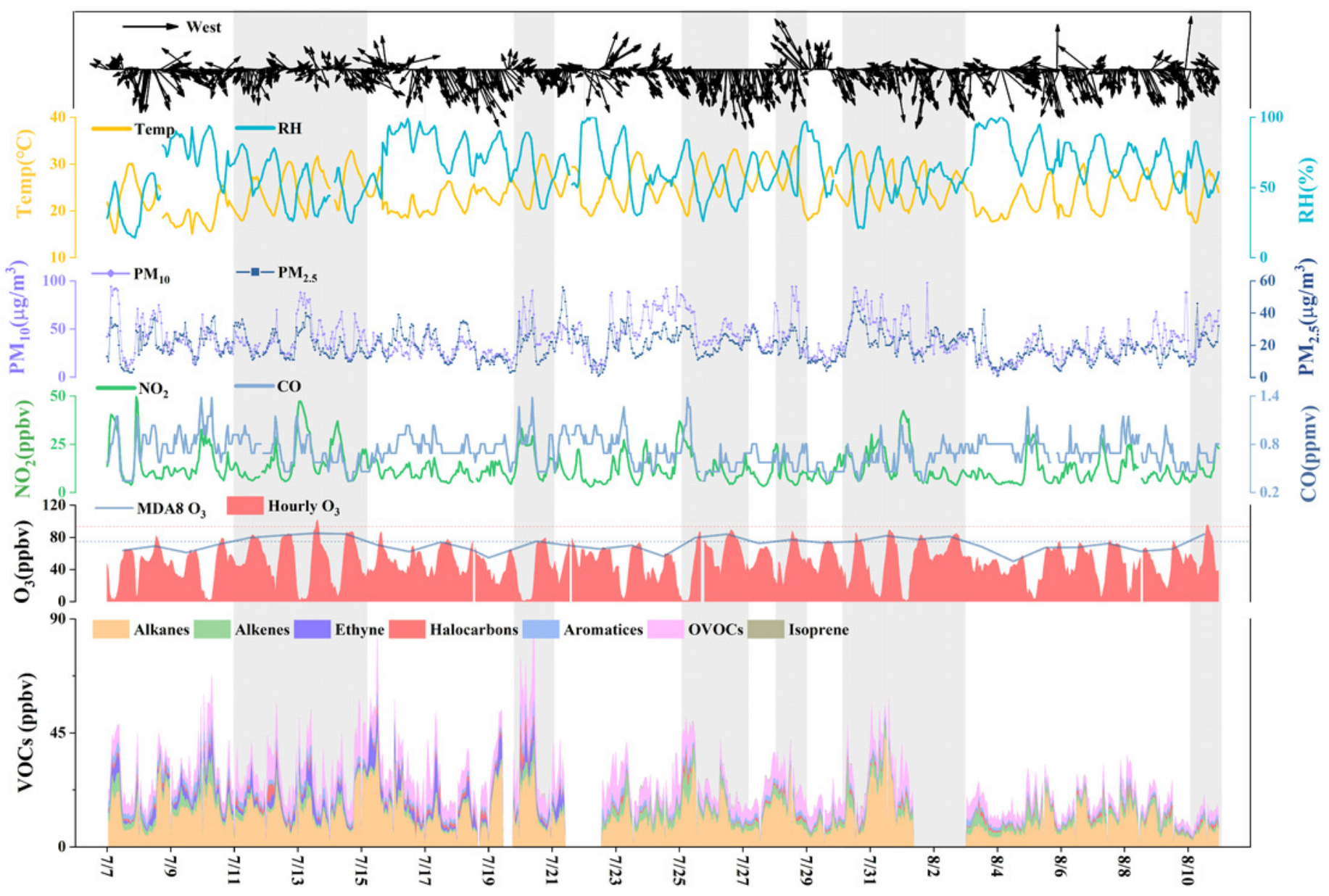


Figure 5

The ratio of concentrations, $\mathrm{OH}$ reaction $\left(\mathrm{L}_{\mathrm{OH}}\right)$ and $\mathrm{O}_{3}$ formation potential (OFP) of alkanes, alkenes, ethyne, halocarbons, aromatics, oxygenated VOCs (OVOCs) and Isoprene.

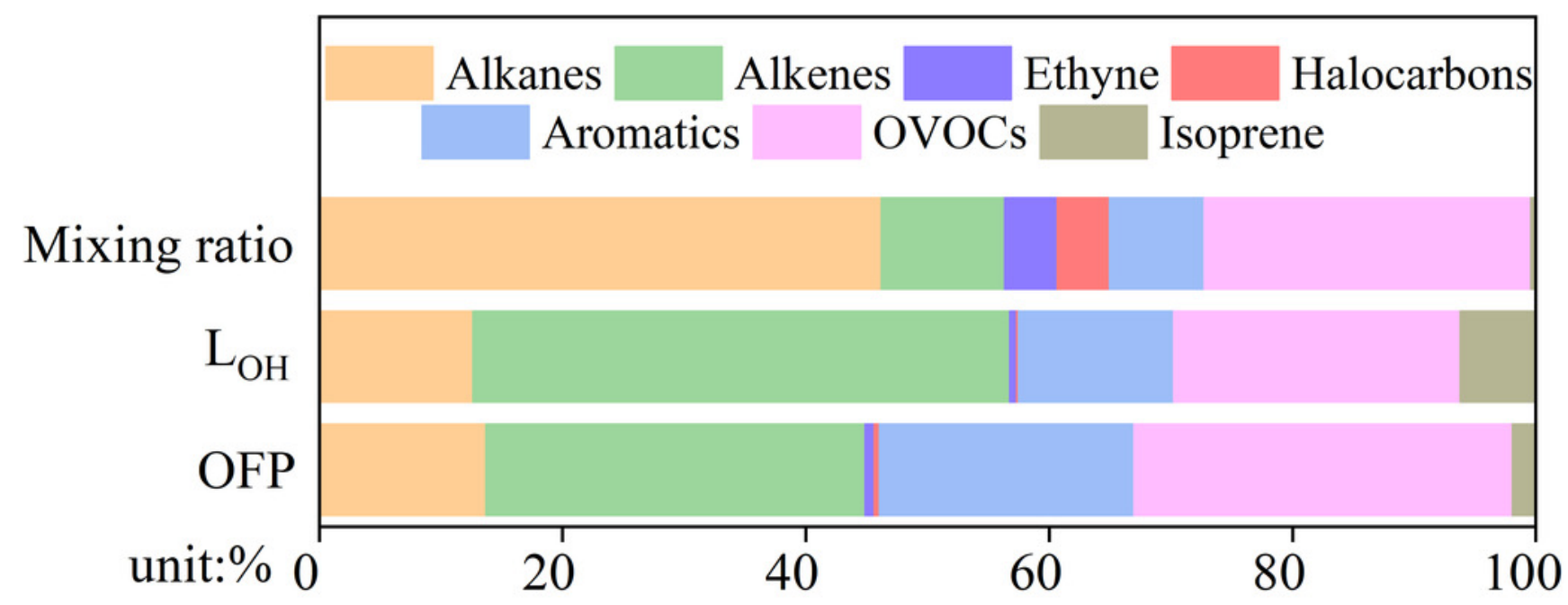


Figure 6

Result of cluster analysis of backward trajectories in Yulin from May to August 2017(a), 2018(b), 2019(c). And the number of polluted trajectories in every cluster.

The backward trajectory with $\mathrm{O}_{3}$ concentrations over $75 \mathrm{ppbv}$ is identified as a polluted trajectory.
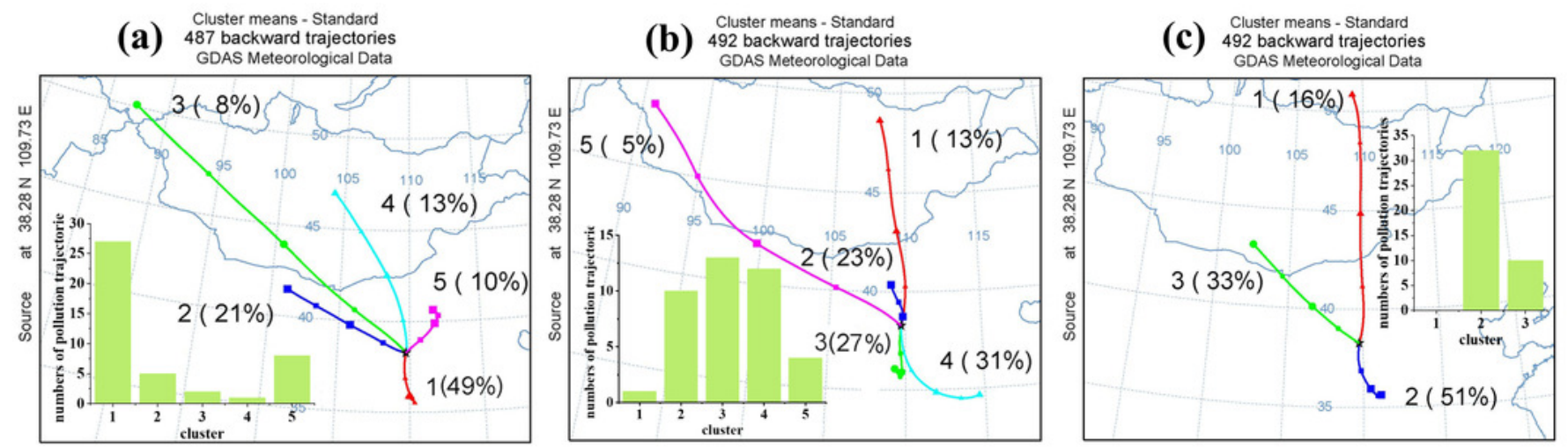
Figure 7

EKMA and Relative incremental reactivity (RIR)

(a) Contour plot of MDA8 as a function of VOC reactivity and NOx concentrations (EKMA), the star represents the base scenario and circles represent $\mathrm{O}_{3}$ pollution days (a) . (b) Relative incremental reactivity (RIR) for AVOCs, isoprene, $\mathrm{CO}$ and $\mathrm{NO}_{x}$ on $\mathrm{O}_{3}$ pollution days.

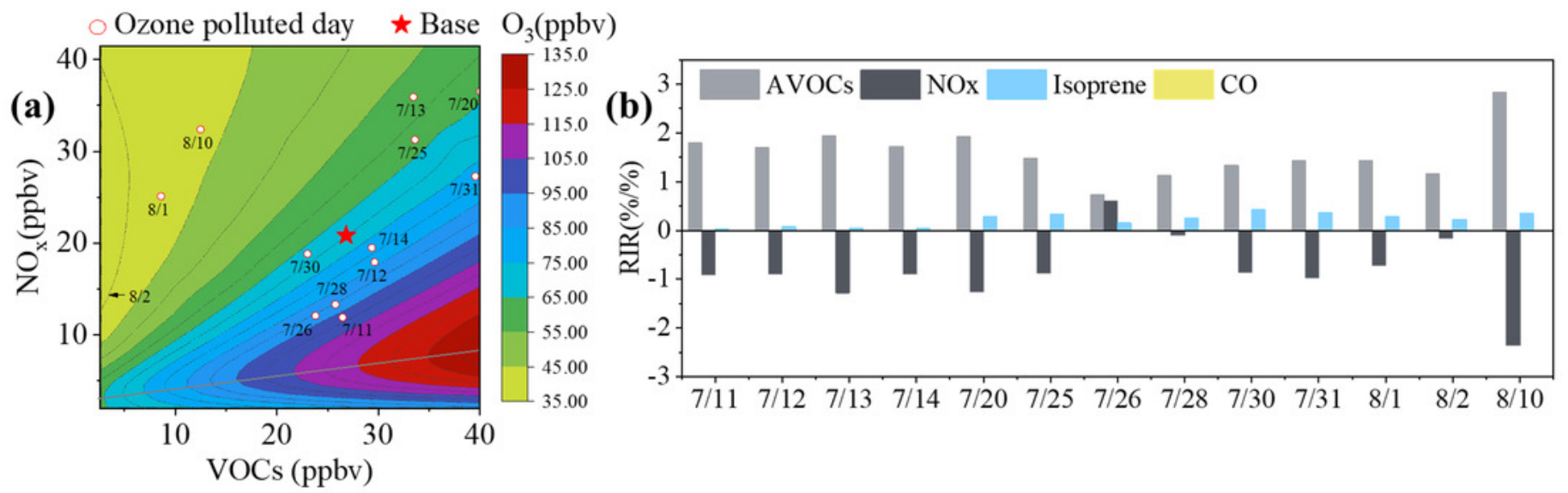


Figure 8

The increment percentage of MDA8 $\mathrm{O}_{3}$ are shown under different $\mathrm{NO}_{x}$ and VOCs reduction pathways and the reduction percentages of $\mathrm{NO}_{x}$ and VOCs.
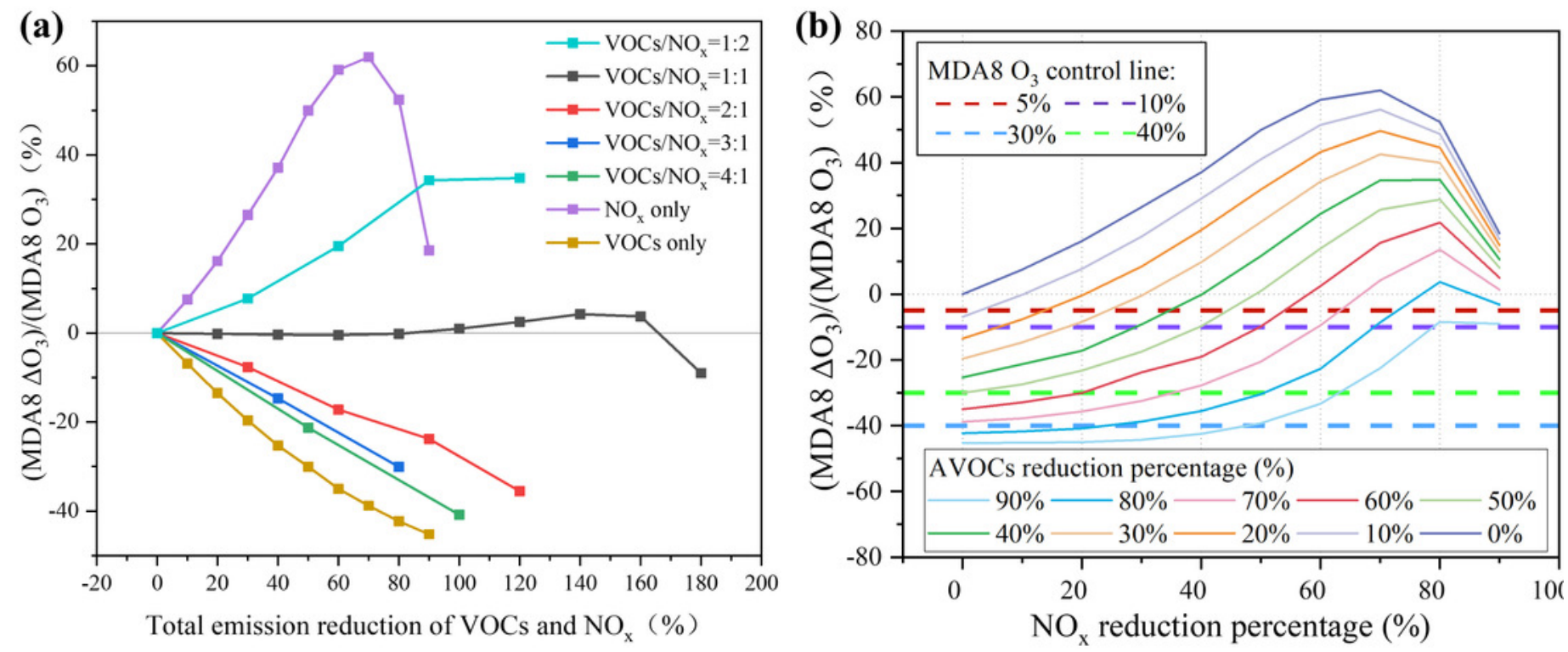


\section{Figure 9}

Relative contributions of different sources to VOCs during study period.
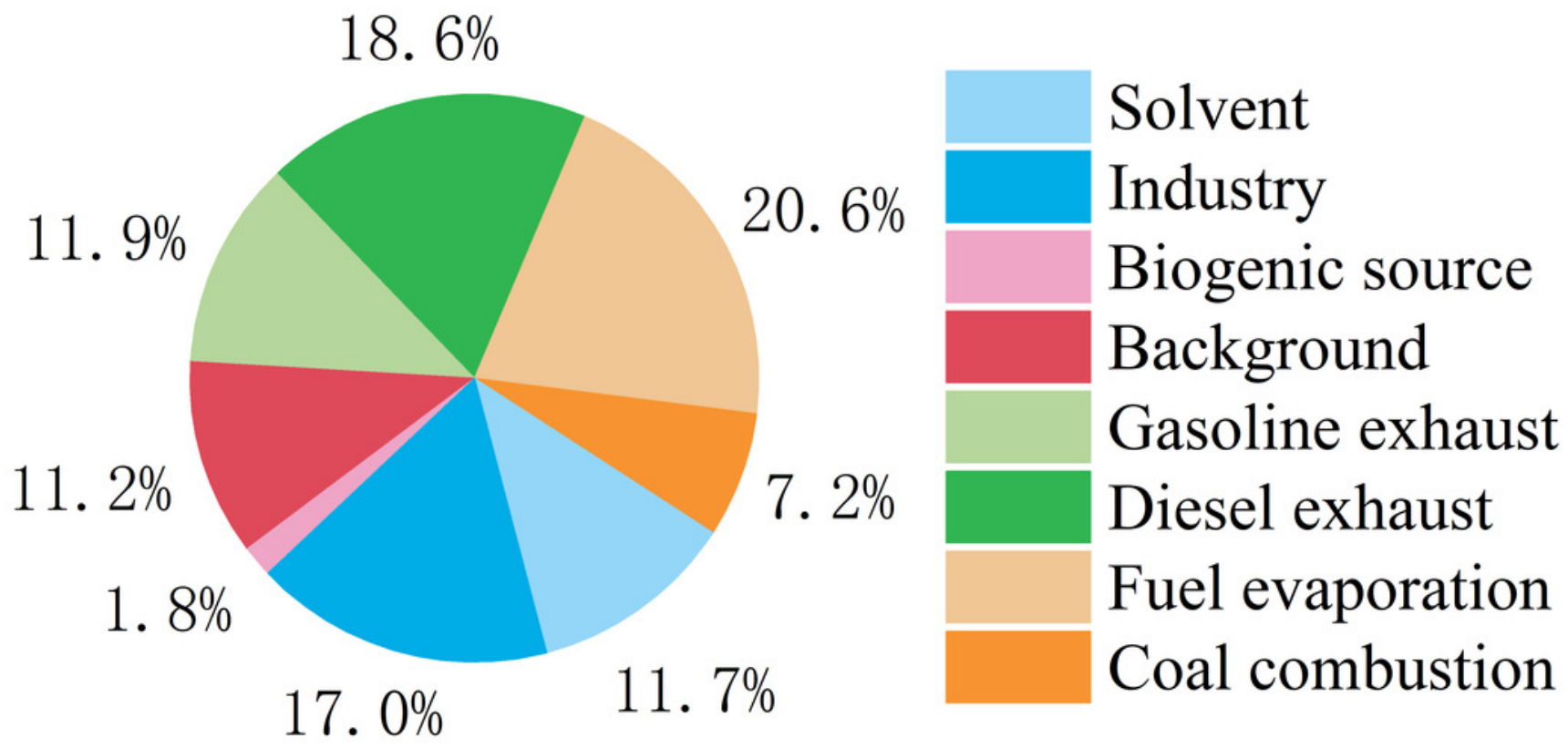


\section{Table $\mathbf{1}$ (on next page)}

Mean daily maximum 8-h average (MDA8) $\mathrm{O}_{3}$ concentrations, the 90th percentile of MDA8 $\mathrm{O}_{3}$ (MDA8-90) concentrations and number of pollution days from 2017-2019. 
Table 1 Mean daily maximum 8-h average (MDA8) $\mathrm{O}_{3}$ concentrations, the 90th percentile

2 of $\mathrm{MDA}_{8} \mathrm{O}_{3}$ (MDA8-90) concentrations and number of pollution days from 2017-2019.

\begin{tabular}{cccc}
\hline Year & $\begin{array}{c}\text { MDA8-90 O3 } \\
\text { ( ppbv) }\end{array}$ & $\begin{array}{c}\text { Mean MDA8 O } \\
\text { ( ppbv) }\end{array}$ & $\begin{array}{c}\text { Number of } \\
\text { pollution days }\end{array}$ \\
\hline $\mathbf{2 0 1 7}$ & 72 & $47 \pm 18$ & 26 \\
$\mathbf{2 0 1 8}$ & 72 & $47 \pm 19$ & 25 \\
$\mathbf{2 0 1 9}$ & 75 & $48 \pm 19$ & 34 \\
\hline
\end{tabular}

3 


\section{Table 2 (on next page)}

Table 2 Relationship between daily average temperature $(T)$, Relative humidity $(\mathrm{RH})$ and Wind speed (WS) and MDA8 and maximum daily 1-hour average $\mathrm{O}_{3}$ concentrations (MDA1). 
$1 \quad$ Table 2 Relationship between daily average temperature ( $T$ ), Relative humidity $2 \quad(\mathrm{RH})$ and Wind speed (WS) and MDA8 and maximum daily 1-hour average $\mathrm{O}_{3}$ concentrations (MDA1)

\begin{tabular}{cccc}
\hline & $\mathbf{T}$ & RH & WS \\
\hline MDA8 & $0.547^{* *}$ & $-0.286^{* *}$ & $-0.088^{* *}$ \\
MDA1 & $0.519^{* *}$ & $-0.250^{* *}$ & $-0.164^{* *}$ \\
\hline \multicolumn{4}{r}{${ }^{* *}$ Correlation is significant at the 0.01 level. } \\
\hline
\end{tabular}

4 